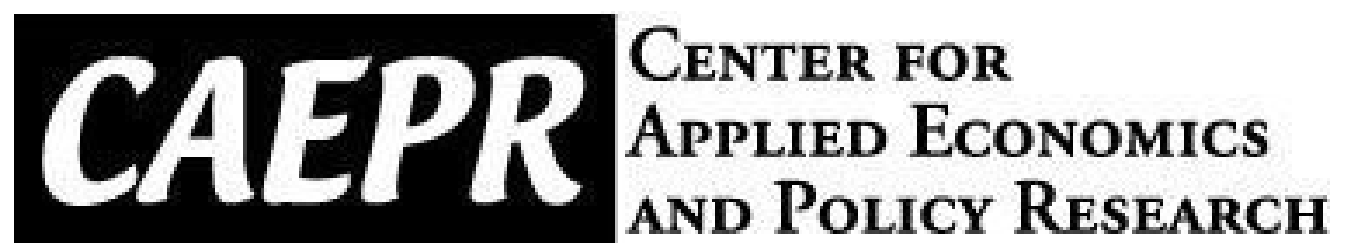

\author{
CAEPR \\ Working Paper \\ \#2018-009
}

\title{
Policy-induced School Calendar Changes and Teacher Moonlighting
}

Gregory Gilpin

Montana State University

August 30, 2018

This paper can be downloaded without charge from the Social Science Research

Network electronic library at https://papers.ssrn.com/sol3/abstract id=3243830

The Center for Applied Economics and Policy Research resides in the Department of Economics at Indiana University Bloomington. CAEPR can be found on the Internet at: http://www.indiana.edu/ caepr. CAEPR can be reached via email at caepr@indiana.edu or via phone at 812-855-4050.

(C)2018 by Gregory Gilpin. All rights reserved. Short sections of text, not to exceed two paragraphs, may be quoted without explicit permission provided that full credit, including (C) notice, is given to the source. 


\title{
Policy-induced School Calendar Changes and Teacher Moonlighting Gregory Gilpin $^{a}$
}

August 30, 2018

\begin{abstract}
Secondary employment (SE) continues to be an important income source for many workers and several influences have been identified that impact engagement. This research studies two of these influences, the hours constraint and job heterogeneity preferences, by analyzing a novel short-lived crisis when California public school switch between 9-month and year-round calendars in response to school capacity constraints caused by education policy reform. This crisis immediately shifted primary employment vacation schedules of full-time teachers for approximately 4-6 school years, potentially altering the composition of SE opportunities. The empirical analysis suggests teachers increase SE engagement by 13.8\% during years their schools are on year-round calendars, and no spillover effects are identified on teachers in nearby schools. The increase is entirely attributable to increases in school-based SE engagement in schools using multi-track year-round calendars, and no change in non-school-based SE engagement is observed. Males and mid-to-late career teachers' SE engagement appears most responsive. The conclusion discusses the relative importance of workers' SE engagement motives and how policy may impact SE engagement.
\end{abstract}

Keywords: secondary employment, dual-job holding, moonlighting, calendar conversion, teacher labor market, vacation schedules

JEL codes: J22, J31

${ }^{a}$ Gregory Gilpin (gregory.gilpin@montana.edu) is an Associate Professor in the Department of Agricultural Economics and Economics at Montana State University-Bozeman, P.O. Box 172920, Bozeman, MT 59717-2920. Ph: (406) 994-5628. 


\subsection{Introduction}

Research has shown that secondary employment (SE) is vital for many workers. ${ }^{1}$ While reasons for SE engagement are vast, research has identified three main determinants: hours constrained at primary employment, risk management, and heterogeneity motives. The relative importance of these determinants remains an empirical challenge due to data limitations. This research extends the literature by studies two important SE determinants: hours constrained at primary employment and heterogeneity motives. The empirical analysis uses a novel short-lived crisis caused by education policy reform that led to the primary employment vacation schedules of full-time California public-school teachers to be altered for approximately 4-6 school years, potentially altering the composition of SE opportunities during this time period.

Over the last two decades, schools have experimented with year-round calendars where the number of instructional days (typically 180 days) is stretched from 9-months to year-round with evenly-spaced smaller breaks. An advantage of year-round calendars is that they also allow schools to overenroll students by assigning students and teachers to tracks that alternate between being 'in school' and 'on vacation'. Changes in school calendars across years provide a unique opportunity to study SE due to primary employment characteristics remaining unchanged, except for vacation schedules. The calendar change may significantly affect these workers' SE opportunities due to the loss of summer break, when workers are typically able to engage in full-time SE without primary employment contractual obligations. On the other hand, year-round calendars allow teachers to substitute teach on their days off in surrounding schools on different calendars or within their own school for teachers on a different track. Teaching is an ideal occupation to study SE as it is one of the largest groups of dual job holders (see Paxon and Sicherman (1996)), is a welldefined occupation, and is a part of a large education sector that contains employment opportunities that require similar human capital to teachers.

The state of California during the late 1990s and early 2000s provides a natural location to study school calendar conversions due to state policy-induced school capacity constraints. During this period, California led the nation with the largest proportion and number of year-round calendar conversions, almost half of all U.S. public schools that converted to year-round calendars (see

1 Moonlighting, supplemental income, secondary employment, and dual job holding are terms commonly used in the secondary employment literature to describe workers who have a primary full-time job and an additional job that could be full or part time. 
Table A.1). At the height of overcrowding in 1999-00 school year, over 20\% of California schools utilized year-round calendars and $66 \%$ of those being multi-track to reduce overcrowding. By midto-late 2000s, school overcrowding reduced significantly due to an expansion in school construction and, by late 2000s, overcrowding fell to below pre-1990 levels, eliminating the use of multi-track year-round calendars completely. While the use of multi-track year-round calendars shrunk during this period, single-track year-round calendars persisted. California's calendar conversions stemmed from overcrowding caused by Proposition 13 that prohibited local education agencies from issuing general obligation bonds to fund school construction projects, substantial population growth of school-aged children, and a class size reduction policy (see Appendix B for historical context). Confronted with larger student enrollment, these policies effectively tied the hands of school administrator with the only option to increase school capacity through using tracking.

The empirical analysis studies change in school calendars on teachers' secondary employment decisions. The analysis is conducted using a repeated cross-section of full-time public-school teachers from four rounds of the restricted-access Schools and Staffing Survey from 1999-2000 through 2011-12. The results indicate that teachers in schools on year-round calendars increase school-based SE engagement by $18.0 \%$, but only in years the schools use year-round calendars, and only in schools using multi-track calendars. Additionally, no change in non-schoolbased SE engagement is observed, regardless of school calendar. Substantial robustness analyses are conducted by teachers' characteristics, timing of calendar conversion, and differentiation of calendars within a teachers' school district.

One implication of this research is the relative importance to SE engagement determinants, i.e., how policy may influence workers' willingness to engage in SE. The results suggest that workers with full-time jobs are willing to increase SE if the human capital requirements are similar to those of the primary employment and only low mobility costs are incurred. Additionally, fulltime workers who engage in SE with dissimilar human capital requirements to primary employment have strong preferences toward employment diversification and are not easily influenced to change their rates of SE engagement, i.e., policy is likely to be ineffective of change their SE engagement. 


\subsection{Background}

\subsection{Secondary employment literature}

Early studies on supplemental income decisions (i.e., moonlighting, and dual job holding) focus on how the number of hours worked at primary employment affects SE engagement, referred to as the hours constraint. ${ }^{2}$ This branch of research suggests that employees may be hours constrained and desire to work additional hours at their current job to increase earnings to their optimal levels, but are unable to do so due to their current employer not offering more hours. Workers increase their labor hours by engaging in SE. While this research is consistent in concluding that the hours constraint is a significant factor in dual job holding decisions, recent studies using more granular data identify several nuances. For example, Frederiksen, Graversen, and Smith (2008) examine the propensity to engage in SE across the income spectrum and find an inverse relationship between the probability of holding secondary employment and workers' current primary earnings. Second, Paxson and Sicherman (1996) and Guariglia and Kim (2006) study the amount of time that a worker holds a second job and find that there is substantial movement in and out of SE and that workers' engagement are often short-term to bridge unemployment in their primary employment. More recent work by Amuedo-Dorantes and Kimmel (2009) find SE duration to also be short term, but procyclical with the business cycle. In contrast, other research argues that the propensity to engage in secondary employment is persistent and not a short-run phenomenon (see Boheim and Taylor, 2004).

The literature has also identified risk management as another primary reason workers engage in SE. Bell, Hart, and Wright (1997) and Panos, Pouliakas, and Zangelidis (2011) both find that workers hold SE to hedge against primary employment losses, thereby ensuring uninterrupted earnings. This finding is similar to Renna, Oaxaca, and Choe (2013) who argue that SE is a substitute for a primary employment change whereby employees can work their optimal number of hours without going through the job search process. Work by Guariglia and Kim (2004) provide further evidence that workers seek SE to smooth consumption over time and hedge against potential negative financial shocks. Evidence of primary employment security affecting SE is

2 This research was initiated by Hamel (1967), Perlman, (1966), Guthrie (1969), Shishko and Rostker (1976) and Krishnan (1990), and was recently revised and extended using more sophisticated empirical techniques (with similar results) by Abdukadir (1992), Kimmel and Conway (2001), Panos, Pouliakas, and Zangelidis (2011), and Renna, Oaxaca, and Choe 2013. 
offered by Boheim and Taylor (2004) who find that the probability of engaging in secondary employment decreases for workers who have permanent primary employment contracts. The literature also finds that workers seek SE to gain new skills and experience to hedge against financial losses sustained from separation from primary employment (Paxson and Sicherman (1996), Heinecke and Schwarze (2004), Panos, Pouliakas, and Zangelidis (2011), and Renna, Oaxaca, and Choe, (2013)). Related to this literature is the desire to enhance workers' human capital and employment portfolio. For example, Allen (1998) and Boheim and Taylor (2004) find that workers decide to engage in SE to enhance their job portfolio while Panos, Pouliakas, and Zangelidis (2011) find that workers acquire new skills during secondary employment that improves workers' occupational mobility. Due to California teacher labor contracts that permit teachers to obtain tenure, this determinant cannot be evaluated.

A voluminous literature exists that study non-monetary influences on SE. Alden (1971) finds that workers in rural areas are more likely to engage in SE relative to their urban counterparts. Krishnan (1990) finds that husbands are less likely to hold a second job if their spouses are employed. Kimmel and Powell (1999) find that unmarried women and younger workers are more likely to engage in SE, while Averett (2011) finds no evidence that there are differential factors between males and females that motivate them to engage in SE. However, Alden and Spooner (1982) point out that there are gender-specific differences in the types of SE held. Specifically, females are more likely to take positions where they are paid employees while men are more likely to be self-employed. Averett (2011) and Panos, Pouliakas, and Zangelidis (2011) cite many different reasons for holding SE, including meeting regular household expenses, paying off debts, saving for future unexpected expenses, gaining experience in a different occupation, staying employed during transition periods between primary jobs, and gaining utility from a second job. Similarly, several studies find that workers may decide to engage in SE due to preferences towards job differentiation (see Renna, Oaxaca, and Choe, 2013).

\subsection{Teacher moonlighting}

The majority of teachers hold SE and there are several factors that potentially influence this decision. First, the teacher labor market is highly contractual and almost all school districts set teachers' annual earnings based on salary schedules, suggesting that teachers may be hours constrained. Second, school calendars dictate teachers' vacation schedules well in advance, 
providing teachers opportunities to engage in SE without holding two jobs simultaneously. Third, the teaching profession is within a large education sector that contains SE opportunities without substantial additional skills; thus, the costs associated with SE engagement may be lower for teachers relative to other professions.

The historical data indicate that in 1964, 16.5\% of U.S. male elementary and secondary teachers engaged in SE (Perlman (1966)). Using more comprehensive earnings data, Paxon and Sicherman (1996) update this statistic and find that between 1976 and 1989, male elementary and secondary teachers had the highest proportion of dual job holding among all occupations, 51.7\%, compared to $31.5 \%$ of female teachers, and $21.1 \%$ for all workers. In addition, of those engaged in SE, $45.5 \%$ and $64.1 \%$ of male and female teachers, respectively, worked within the education sector. During this time, teachers' SE hourly wage to primary employment hour wage was 0.921.07 with a median of $0.75-0.88$, suggesting that teachers were willing to work for less than their wages as a teacher.

I update these descriptive statistics using the Schools and Staffing Survey (SASS) between 1999-2000 through the 2011-12 school years and display them in Table 1. The SASS classifies SE by whether it is school-based (e.g., coaching, running the concession stands at athletic events, substitute teaching, teaching summer school, mentoring teachers, teaching evening courses) or non-school-based (e.g., tutoring, non-teaching, but related to the teaching field, and other). The descriptive statistics suggest that $58.9 \%$ of all U.S. full-time elementary and secondary publicschool teachers hold SE between 1999 and 2012. Broken down by gender, 76.5\% of male teachers and 53.2\% of female teachers engaged in SE. Comparing these rates of engagement to Paxon and Sicherman (1996) indicates that male teachers have increased their rates of dual job holding by approximately 25 percentage points, while female teachers have increased their rates by 22 percentage points. The table also shows substantial variation in engagement by type of SE; 49.9\% of teachers hold school-based SE (65.3\% of male teachers and $44.9 \%$ of female teachers) while 23.4\% of teachers hold non-school-based SE (19.2\% of female teachers and $36.4 \%$ of male teachers). Within non-school-based SE, more than half is unrelated teaching. ${ }^{3}$

\footnotetext{
3 The table also provides summary statistics for California public school teachers, the primary group analyzed, and indicates these teachers have very similar SE engagement.
} 


\subsection{Data}

The empirical analysis is conducted using a sample of full-time public-school teachers in California. The primary data source on teachers and schools is the restricted-access versions of the Schools and Staffing Survey (SASS) for school years 1999-2000, 2003-04, 2007-08, and 2011-12. While the SASS is one of the richest teacher-level dataset on U.S. teachers, containing teachers' school environment characteristics and substantial teacher background characteristics, the SASS does not follow the same teachers over time. Thus, this repeated cross-sectional data contain similar information on different samples of teachers over the 13-year period.

The SASS includes teachers’ background characteristics, including work environment characteristics, and information on SE engagement. The information on SE include whether the teacher engaged in SE during the year and whether SE engagement was school-based or nonschool-based. ${ }^{4}$ The survey also asks about other income such as merit compensation, pay-forperformance, and retirement pension income. These other income sources are included as primary employment compensation.

The individual's background characteristics include gender, race, age, teaching experience (highly correlated with age), and a proxy for geographic preference measured by whether the individual earned a bachelor's degree from a California college or university. This information permits evaluation of individual-specific covariates. The data also provide a wide variety of school and student body characteristics for where the teacher is employed: working in an elementary school (K-8), a combined school, or secondary school (9-12), the percent of students eligible for free lunch, who are minorities, who have individual education plans, and whether the school is located in a rural, urban, or metropolitan area.

School calendar information is provided by the California Basic Education Data System and includes whether the school is on a 9-month or year-round calendar and how many tracks the school utilizes. There are four different types of calendars studied: traditional 9-month, singletrack year-round, Concept 6 (3-track) year-round, and 4-5 track year-round. Concept 6 calendar has the greatest school utilization and increases maximum enrollment capacity to $150 \%$, compared

\footnotetext{
${ }^{4}$ Due to survey limitations, secondary employment during the summer versus the school year cannot be separated. Additionally, it is unclear how teachers on year-round calendars would answer summer employment questions.
} 
to $133 \%$ for school using a 4-track calendar (Mitchell (2002)). ${ }^{5}$ For example, using a 4-track calendar, a school with the capacity for 750 students can accommodate 1,000 students with three tracks of 250 students each in school and one track on vacation at any given time.

The analysis also controls for local labor market conditions surrounding teachers' schools. First, the local area wage gap between teachers and non-teachers is calculated by subtracting the log of county-level per capita real income, provided by the Bureau of Economic Analysis (BEA), from the log of individuals’ primary employment earnings. Typically, local real average income would be included in labor participation regressions but is excluded in this analysis due to the high correlation with the percent of students eligible for free lunch (common in the economics of education literature). Second, local area unemployment rates are provided by the Bureau of Labor Statistics (BLS). Third, the percent of school-based funding and annual population growth are provided by the U.S. Census Bureau.

The data are restricted to teachers that work in schools that, at some point during the sample period, switched between 9-month and year-round calendars. This is done as there is likely several differences in attributes (both observed and unobserved) between schools in areas that never change their school calendars and those that do. The final sample consists of 4,490 full-time publicschool teachers within California. ${ }^{6}$ The summary statistics on all variables included in the analyses are provided in Table 3.

\subsection{Empirical Strategy}

\subsection{Identification}

California’s Proposition 13 passed in 1978 and initiated sweeping changes to the state and local property tax systems. This proposition limited property tax rates and prohibited local education agencies (LEAs) from issuing general obligation bonds to fund school construction projects. These limitations effectively shifted local school construction and renovations to the state who

\footnotetext{
${ }^{5}$ Concept 6 is a 3-track year-round calendar requiring only 163 school days per track, compared to the standard 180, and increases the school day to achieve required annual instructional time. In 2000, Williams et al. vs. California successfully challenged the constitutionality of Concept 6 and in the fall of 2004 Assembly Bill 1550 prohibited new schools from operating under a Concept 6 calendar and required school districts to submit plans to eliminate the Concept 6 calendar prior to July 1, 2012.

${ }^{6}$ The reported sample and subsample sizes are rounded to the nearest 10 as per license restrictions.
} 
implemented the State Allocation Board. Due to slow procurement and insufficient state funds, new school buildings did not keep pace with record-setting school-aged population growth. ${ }^{7}$ In an effort to reduce overcrowded schools, in 1998, the California legislature and Governor Pete Wilson establish a class size reduction (CSR) program that mandated caps on the number of students per certified teacher in various grades. This research-based mandate supported by the California Teachers Association immediately created overcrowding in otherwise uncrowded schools (Bohrnstedt and Stecher (1999)). Due to expanding enrollment, prohibited locally financed school construction, and the CSR program, schools had no choice but to switch to year-round calendars that expanded school capacity.

Overcrowding is observed by facility utilization rates. Using the Common Core of Data, the average number of students per school, teachers per school (measured in FTEs), and the change in the number of schools are described in Figure 1. The historical data indicate that during the late 1980s and early 1990s, California public schools had, on average, more students per schools than the national average (650 vs. 500) and an approximately equal number of teachers per school (28). To combat higher enrollments, schools converted to multi-track year-round calendars. Additionally, in anticipation to multi-tracking, some schools converted to single-track year-round calendars to acclimate students and teachers. During 1999, expanding school enrollment persisted and school construction remained stagnant, increasing the number of students and teachers per school to approximately 700 and 32, respectively.

At the beginning of the millennium, school overcrowding became a serious concern for policymakers and voters. Over 20\% of California's schools were on year-round calendars and 2/3 of those utilized multi-track calendars (see Figure 2). ${ }^{8}$ Four state laws targeted the epidemic to increase school construction. Proposition 39 re-established local general obligation bonds, leading to $\$ 1.1$ billion in school construction between 2000 and 2015. Variation by the vote passage thresholds caused stark differences in election outcomes across districts. In three consecutive general elections between 2002 and 2006, Proposition 47, 55, and 1D authorized \$13.1 billion (in 2002 dollars), \$12.3 billion (in 2004 dollars), and \$10.4 billion (in 2006 dollars) to support

\footnotetext{
${ }^{7}$ See Appendix B for a complete historical account of these propositions and their impact on public schools.

${ }^{8}$ See Appendix A for an overview on calendar changes background and its effect on student outcomes.
} 
matching grants for school construction projects. ${ }^{9}$ Overall, these grants funded 10,085 primary and secondary school facility projects. The increased use of facilities persisted during this time and fall of 2005 was a turning point with 527 new schools opening, greatly reducing schools reliance on tracking. School construction continued, resulting in a reduction in school utilization of 640 students and 30 teachers per school by 2007 (see Figure 1).

The reliance on year-round school calendars during 1999-00 to 2011-12 is observed in Figure 2 and Table 2. During this period, 1,811 California schools converted to year-round calendars. ${ }^{10}$ Of these, 648 schools were single-track conversions, 674 schools were multi-track conversions, and 489 schools experimented with both single- and multi-tracks. The average duration on a year-round calendar for those that converted was 6.0 school years and duration varies by track conversion. Schools deploying single-track calendars did so for 6.1 years, while schools deploying solely multi-track calendars did so for 6.6 years. Those that deployed both single- and multi-track calendars had the longest duration of use of 9.0 years. Overall, during the sample period, there was a net conversion loss of year-round calendar use (reverting back to 9-month calendars), a net conversion gain of single-track year-round calendar conversion, and a net loss of multi-track year-round calendar conversions. The use of year-round calendars declined slightly through the 2007-08 school year to $11 \%$ of all California schools, followed by rapid decline to $7 \%$ by the 2011-12 school year (see Figure 2). At this point in time, all year-round calendars are single track with multi-track calendars discontinued.

The impact of local education bond passage on California school facility investments during 1987-2006 has been studied by Cellini et al. (2010) and recent analysis has been conducted by Dayton (2015). Their work established the randomness of school construction across California due to variable local bond passage thresholds. The relationship between local education bond passage and calendar use is provided in Figure 3. The graphic displays the average proportion of

\footnotetext{
${ }^{9}$ Ed-Source, the provider of the school-district level general obligation bond data, indicated that these data should not be interpreted as school construction bonds. Rather, there are several nonconstruction reasons that school districts present bonds to its constituents, such as raising teachers' salaries. The data indicate a large portion of bonds purchase land, renovate buildings, and finance new construction.

${ }^{10}$ The data indicate that, on average, half of schools within a district were on a year-round calendar during the sample period of those districts that had at least one school on a year-round calendar. There is no distinct relationship observed in the data between calendar use and elementary/secondary school status.
} 
schools on multi-track school calendars by whether their LEAs' general obligation bond passed or failed during the sample period. In years leading up to a bond vote, approximately 5.2-6.6 percent of schools used multi-track calendars and little difference in calendar use is observed between the group of schools that successfully passed their bonds and those that did not. The year after bond election, schools' use of multi-track calendar changes distinctly depending on the bond vote outcome. For the group of schools that their LEAs passed their bonds, their reliance on multi-track calendars decreased by approximately 2 percentage points after four years, a 30\% decline in the probability of using multi-track calendars. The lag effect is expected due to school construction time. For the group of schools that their LEAs do not pass their bonds, their reliance on multi-track calendars immediately rose by 2-3 percentage points, an approximately $50-75 \%$ increase in the probability of using multi-track calendars. For reference, the use of multi-track year-round calendars among schools with no LEA bond vote during the sample period is approximately $4.0 \%$, with annual variation between 3.8-4.5\%.

Due to the asymmetric use of multi-track calendars in response to bond passage, a reduced form relationship is analyzed between calendar use and SE engagement. Additionally, schools did not necessarily convert from multi-track year-round calendars to traditional 9-month calendars after school construction, and instead opting for single-track year-round calendars. Moreover, it is not clear that the new school would retain the calendar schedule of the school being split. Nonetheless, in both single and multi-track calendars, teachers no longer have a blocked summer break.

\subsection{Empirical Specification}

The empirical analysis uses the timing of calendar conversions within the sample period that drive differences in teachers' primary vacation schedules and the compositions of SE opportunities to estimate changes in teachers SE engagement. As mentioned above, only teachers who worked in a school on a year-round calendar sometime during the sample period are included. ${ }^{11}$ The baseline model specification is:

$$
S E_{\text {ist }}=\alpha+\beta_{1} I\left(Y R_{\text {st }}\right)+\beta_{2} X_{i t}+\beta_{3} X_{s t}+\beta_{4} X_{c t}+\delta_{d}+\delta_{u}+\delta_{t}+\varepsilon_{i d t}
$$

\footnotetext{
${ }^{11}$ In robustness regressions, the sample is expanded to all teachers in districts with at least one school on a year-round calendar.
} 
where $S E$ is an indicator variable for whether teacher $i$ in school $s$ during school year $t$ is engaged in secondary employment, $X_{i}$ are teacher characteristics, $X_{s}$ are school/student body characteristics where the teacher is employed, and $\delta_{j}$ are sets of fixed effects for urbanacity where the teacher works $(j=u)$, school district $(j=d)$, and school year $(j=t) .{ }^{12}$ The variable of interest, $I\left(Y R_{s t}\right)$, is an indicator variable identifying whether school $s$ is currently on a year-round calendar at the beginning of school year $t$ and 0 elsewise. In robustness analyses, alternative specifications of school calendar variable are explored such as the timing of calendar change and calendar track type. The regression equation is estimated using a linear probability model. The standard errors are clustered at the district level. The coefficient estimate on year-round calendar is easily interpreted as the average percent change in SE engagement. ${ }^{13}$

One concern to the identification strategy is that teachers may respond to the calendar conversions and transfer between schools on different calendars. There is substantial evidence that suggest teachers' decisions on primary employment do not include school calendar changes. First, in an unpublished conference proceeding, Graves, McMullen, and Rouse (2014) show that teachers do not respond to calendar changes by moving between schools or exit the teaching profession. Moving between schools or exiting teaching requires substantial costs, e.g., travel costs, new principal, team, and staff, and often a new grade preparation, likely in excess to the benefit of the short duration of year-round calendar usage. Their analysis is extended by comparing descriptive statistics of teachers' primary employment characteristics. Table 4 provides T-tests between these two groups of teachers and fails to reject that teachers' annual earnings, annual hours worked, experience, gender, and attrition are equal.

\footnotetext{
12 A standard difference-in-difference model specifies school fixed effects and an indicator for whether the school uses a year-round calendar during school year $t$. The data is repeated crosssection and do not follow the same schools over time, limiting the use of school fixed effects. This analysis is in the spirit of difference-in-difference estimation.

${ }^{13}$ While district-by-year fixed effects are possible, initial estimates suggested the model was overspecified to provide meaningful results due to too few observations per district for each year.
} 


\subsection{Results}

\subsection{Main results}

Prior to regression analysis, some descriptive statistics on teachers' SE engagement during the period are presented in Table 5. Teachers are grouped by whether in schools that remain on 9month calendars the entire sample period, by whether in schools currently on year-round calendars, or by whether in schools that converted to a 9-month calendar sometime during the sample period. The data suggest that $60.0 \%$ of teachers in schools that remain on a 9-month calendar the entire sample period engage in SE, extremely similar to the national average. In contrast, $81.8 \%$ of teachers in schools that are currently on year-round calendars engage in SE. Engagement falls to $47.6 \%$ in schools that convert back to 9-month calendars. Separating SE engagement by schoolbased and non-school-based suggests that $55.6 \%$ of teachers in schools that remain on a 9-month calendar during the entire sample period engaged in school-based SE, compared to $77.3 \%$ of teachers in schools currently on year-round calendars and $41.0 \%$ of teacher in schools that switched to 9-month calendars. ${ }^{14}$ Non-school-based SE engagement is $16.2 \%-19.9 \%$, and no meaningful differences are identified between teachers across schools.

The full regression results are provided in Table 6. First, few individual covariates are significant. Teachers with higher primary earnings are more likely to engage in school-based SE. This may reflect that schools with higher pay also have more extracurricular opportunities as well, or that higher able individuals earn more in the primary and secondary labor markets. A negative correlation between age and non-school based SE engagement is observed, and this correlation diminishes with age. Second, few school characteristics impact teachers' SE. Teachers in secondary schools are more likely to engage in SE than teachers in elementary schools, both school-based and non-school-based.

The results indicate that the teachers' SE engagement increases by $13.8 \%$ in schools on a year-round calendar, controlling for teacher, school, and community covariates as well as district and year fixed effects. Additionally, the estimation results by type of SE follow the summary statistics; teachers in schools that are currently on a year-round calendar are $18.0 \%$ more likely to

\footnotetext{
${ }^{14}$ Some teachers may hold both school-based and non-school based secondary employment. Triple versus dual job holdings is not analyzed as the rate of incidence is too small.
} 
engage in school-based SE than teachers in schools that are no longer on year-round calendars. ${ }^{15}$ The estimation results provide little support that calendar conversions are correlated with nonschool-based SE, suggesting stronger job heterogeneity preferences than workers who engage in school-based SE.

Table 7 displays the results from a sensitivity analysis and provides evidence of coefficient stability for all types of SE categories, i.e., time-varying differences between teachers, schools/student bodies, and communities do not appear to be driving the main results. The sensitivity analysis builds up from a parsimonious model with only district fixed effects, Model 1, to the full specification, Model 6, i.e., main results from Table 6, displayed for convenience. Model 2 additionally includes year fixed effects, while Models 3 - 5 separately add teacher, school/student body, or community covariates. These six models are estimated for each SE category for a total of 18 regressions. Table 6 only displays the coefficients and standard errors for the year-round calendar indicator variable, observation counts, and $R^{2}$ (full results available upon request). Accounting for all sources of SE engagement, the estimates suggest the change in SE engagement for teachers in schools currently on a year-round calendar is between 13.3\%-15.4\% across all model specifications. ${ }^{16}$ The largest change in the coefficient size occurs when year fixed effects are applied from Model 1 to Model 2, is less than a 2 percentage points difference, and likely attributable to changes in the business cycle during the sample period. The results also suggest that adding either teacher, school/student-body, or community covariates do not change the impact by more than $0.5 \%$, a reasonable tolerance level relative to the sample mean of $59 \%$ SE engagement. The sensitivity analysis also suggests no differential impact with and without all covariates, i.e., coefficient stability is observed when comparing Model 2 to Model 6. The results from the estimating the impact on school-based SE indicate that across all model specifications, the same general magnitude is identified of a $17.9 \%$ to $19.5 \%$ increase in SE engagement. Additionally, no estimated effect is ever identified on non-school-based SE engagement. The results of this sensitivity analysis suggest coefficient stability and that differences between teachers, schools/student bodies, and their surrounding communities are not altering the results.

${ }^{15}$ Using this same specification, the log of secondary employment earnings is explored and no significant effects are identified, suggesting that SE earnings may be diffused among more teachers who are currently in schools on year-round calendars.

16 The estimate is slightly lower, $11.2 \%$, when no sampling weights are applied. 


\subsection{Subsample Analysis}

Due to differential labor markets, subsample regression analyses are conducted by gender and age, and by whether the teacher is in an elementary or secondary school. Equation (1) is estimated on the subsamples and the results are provided in Table 8. To conserve space, only the coefficient on the year-round calendar indicator variable is displayed and full results are available upon request. These analyses indicate that male teachers in schools currently on year-round calendars significantly increase their SE engagement by $25.3 \%$, compared to $10.9 \%$ for female teachers (though not significantly). The results by type of SE fortify the main result that suggests teachers in schools currently on year-round calendars increase their school-based SE, but not their nonschool-based SE.

Subsampling teachers by age indicate that teachers 30 years of age and older in schools currently on year-round calendars increase their SE engagement. This is compared to teachers under the age of 30 who do not increase their SE engagement significantly. These results may reflect that newer teachers dedicate more hours to their primary employment to build their curriculum and also may be attending graduate education to move up along the salary schedule. Another reason may be due to the way school-based SE is filled. For example, if positions are filled based on seniority, teachers under 30 would be the last to obtain SE. The SE literature suggests that younger workers engage in SE more than older workers. While these results indicate that this relationship doesn't hold for those under 30 years of age, it does hold for those between age 30 to 39 and over 40. Subsampling teachers by whether they work in elementary and secondary schools indicate that both elementary and secondary school teachers increase their rates of schoolbased SE when their schools are on a year-round calendar. The results also do not identify changes in non-school-based SE.

The results suggest the cost of SE may influence teachers' decision to engage in SE. For example, school-based SE is local and likely has little-to-no additional travel costs as well as lowto-no additional human capital investments. Moreover, school-based SE search and application costs are likely quite low. It is important to recognize that school-based SE increases and this requires an increase in school-based SE opportunities. It is unlikely that school administrators simply acquiesce to teachers' demands for more school-based SE, which may question the validity of these results. One explanation is that teachers in schools with year-round calendars engage in 
substitute teaching during their breaks in another school (presumably on 9-month calendars) or in their own school for a teacher on a different track.

\subsection{Analysis of whether all teachers within a district with at least one school on a year-round calendar increase SE engagement}

One question is whether the change in SE is limited to solely teachers within the school on the year-round calendar. Potentially, all teachers could substitute teach for each other within the same district as long as they were on different calendars. To test this hypothesis, the sample is expanded to include all schools within a district with at least one school on a year-round calendar. This increases the sample to 5,600 teachers. ${ }^{17}$ Additionally, the year-round calendar indicator variable in the baseline model, Equation (1), is now defined as whether a school within the district is on a year-round calendar during school year $i$. It should be noted that district fixed effects cannot be included due to collinearity with this binary variable. The abbreviated results are displayed in Table 9a and indicate that teachers within the district do not change SE engagement when at least one school is currently on a year-round calendar. These results suggest that the impact is localized to just the workers being directly affected by the calendar change and no spillover effects are identified on other workers. These results validate the above argument that there are differential costs of school-based SE engagement for teachers currently in a school on a year-round calendar and other teachers within the same district.

\subsection{Analysis of track type}

Another question is whether type of year-round calendar conversion influences SE. The number of tracks greatly alters teachers' ability to substitute teach within the same schools. The year-round calendar binary is subdivided by track: single-track, 3-track (Concept 6), and 4-5-track. Single track year-round calendars do not offer teachers the ability to substitute for each other within the same schools as they all have vacation at the same time. 3-track year-round calendars do permit teachers to substitute for at least one other track as the school has 1 track on break and 2 tracks in school on any school day. It also shortens the school year by 17 days. 4 and 5-track year-round calendars provide the most opportunities to substitute teach within teachers' schools as either 3 or

\footnotetext{
${ }^{17}$ Observation counts rounded to nearest 10 as per data license agreement.
} 
4 tracks are in school and one track is on break on any given school day. The model specification is now:

$$
\begin{aligned}
S E_{i s t}=\alpha+\beta_{1} I & \left(1 T_{s t}\right)+\beta_{2} I\left(3 T_{s t}\right)+\beta_{3} I\left(45 T_{s t}\right) \\
& +\beta_{4} X_{i t}+\beta_{5} X_{s t}+\beta_{6} X_{c t}+\delta_{d}+\delta_{u}+\delta_{t}+\varepsilon_{i d t}
\end{aligned}
$$

where $I\left(1 T_{s t}\right), I\left(3 T_{s t}\right)$, and $I\left(45 T_{s t}\right)$ are the year-round calendar variables as discussed above and the coefficients of interest are $\beta_{1}$ through $\beta_{3}$ and estimate the separate impacts of teachers' SE engagement in schools currently on a year-round calendar, and are based on the number of tracks. Note that all year-round calendar binary variables are zero for schools that were on a year-round calendar sometime during the sample period (but not currently).

The abbreviated results include the year-round calendar coefficients and are provided in Table 9b. These results indicate that teachers within schools currently on multi-track year-round calendars increase school-based SE by 33.7\%-35.2\% and no effects are identified in schools that currently use a single-track year-round calendar. The increase in SE engagement is larger in schools with 4-5-tracks than 3-tracks, suggesting that the opportunities to engage in school-based SE may be greater in schools with more tracks. These results suggest that the costs of SE engagement are important and the impact appears isolated to teachers engaging in SE at their primary employment location and that these workers are attempting to increase their income at their current employer, i.e., hours constrained.

\subsection{Analysis of Calendar Change Timing}

The above baseline analysis is extended to study the impact of the timing of school calendar conversion. This is conducted to assure that there is not something different about these schools and that teachers did not alter their SE engagement prior to the calendar change. The baseline time index on the calendar variable is contemporaneous and is extended by lagging and leading, i.e., the year-round calendar binary variable is modified into a time index of when school calendars changed. Due to schools only remaining on a year-round calendar for approximately 4-6 years, only two lags and two leads are created for a total of five year-round calendar binary variables. If estimated impacts are identified prior to a calendar change, then this provides evidence that 
something other than the change in calendar is driving the results. The four binaries time index variables are exchanged in the baseline specification for the year-round binary variable as follows:

$$
S E_{i s t}=\alpha+\sum_{j=-2}^{2} \beta_{j} I\left(Y R_{s t+j}\right)+\beta_{5} X_{i t}+\beta_{6} X_{s t}+\beta_{7} X_{c t}+\delta_{d}+\delta_{u}+\delta_{t}+\varepsilon_{i d t}
$$

where $I\left(Y R_{s t+j}\right)$ is the year-round calendar indicator variable index to school year $j$. Since these binary variables are colinear, the omitted year-round calendar variable is the year prior to the calendar change, $j=-1$. The year-round calendar variables' coefficients are interpreted as the change in SE engagement relative to SE engagement the year prior the calendar change.

The abbreviated results from the estimations are provided in Table 9c. The results are as follows. First, no change in SE engagement is observed two-years prior to the calendar change, relative to the year prior to the calendar change. Second, there is a significant change in SE engagement in the year of calendar change of approximately the same magnitude as the baseline estimates that include all years schools are on year-round calendars. Furthermore, there is substantial inertia in SE engagement post-calendar change. The estimated impact one year after year-round calendar conversion is $13.8 \%$ and this grows to $21.6 \%$ in the second year. The increase in SE engagement is solely attributable to increases in school-based SE engagement.

\subsection{Conclusion}

Secondary employment continues to be vital for many workers. Reasons for engagement are vast and empirical identification remains challenging. This study uses changes in teachers' primary employment vacation schedules that alter the composition of the secondary employment opportunities to identify how these workers respond. Specifically, this research uses changes to school calendars between 9-months and year-round, directly attributable to policy-induced overcrowding, that altered workers' vacation schedules, to understand SE engagement behavior. The estimation relies on changes in school calendars not affecting the primary employment characteristics. The results of this research find that teachers increase their SE engagement when schools convert to year-round calendars, but only when schools are on year-round calendars. Additionally, only teachers within the school with the calendar change their school-based SE, and teachers within surrounding schools do not change their SE engagement. The results also suggest 
no change in non-school-based SE engagement, indicating strong preference toward employment diversification.

One implication of this research is how public policy may influence workers' willingness to engage in SE. The results of this paper suggest that workers with full-time jobs are willing to increase SE engagement if human capital requirements are similar to that of primary employment and personal costs are quite low, i.e., policy can influence more workers to engage in SE if the associated personal costs are low. On the other hand, full-time workers are unwilling to change SE engagement if their chosen SE has dissimilar human capital requirements to that of their primary employment, i.e., policy does not greatly influence the SE engagement decisions of workers with stronger job heterogeneity preferences. 


\section{References}

Abdukadir, G. (1992). Liquidity Constraints as a Cause of Moonlighting. Applied Economics, 24(12): 1307-1310.

Alden, J. (1971). Double jobholding: A Regional Analysis of Scotland. Scottish Journal of Political Economy, 18(1): 99-112.

Alden, J. and Spooner, R. (1982). Multiple job holders: An Analysis of Second-jobs in the European Community. Luxemburg: Office for Official Publications of the European Communities.

Alexander, K. , Entwisle, D., and Olson, L. (2007). Lasting Consequences of the Summer Learning Gap. American Sociological Review,72(2): 167-180.

Allen, D. (1998). The Moonlighting Decision of Unmarried Men and Women: Family and Labor Market Influences. Atlantic Economic Journal, 26(2): 190-205.

Allinder, L., Fuchs, D., and Hamlett, C. (1992). Effects of Summer Break on Match and Spelling Performance as a Function of Grade Level. The Elementary School Journal, 92(4): 451460.

Amuedo-Dorantes, C., and Kimmel, J. (2009). Moonlighting Behavior over the Business Cycle. Economic Inquiry, 47(4): 754-765.

Averett, S. (2001) Moonlighting: Multiple Motives and Gender Differences. Applied Economics, 33, 1391-1410.

Bell, D., Hart, R. and Wright, R. (1997) Multiple Job Holding as a 'Hedge' Against Unemployment. CEPR Discussion Paper No. 1626.

Boheim, R. and Taylor, M. (2004) And in the Evening She’s a Singer with the Band: Second Jobs, Plight or Pleasure? IZA Discussion Paper No. 1081. Bonn, Germany: Institute for the Study of Labor.

Bohrnstedt, G. and Stecher, B. (1999). Class Size Reduction in California: Early Evaluation Findings, 1996-1998. Technical Report. CSR Research Consortium.

California Legislative Analyst's Office (1986). Financing School Facilities. Retrieved from http://www.lao.ca.gov/reports/1986/school_facilities_022086.pdf. 
Cellini, S., Ferreira, F., and Rothstein, J. (2010). The Value of School Facility Investments: Evidence from a Dynamic Regression Discontinuity Design. Quarterly Journal of Economics, 125 (1): 215-261.

Coleman, R., and Freehorn, C. (1993). A Comparative Study of Multi-Track Year-Round Education and the Use of Relocatables. Paper presented at the annual meeting of NAYRE, San Diego, CA.

Common Core of Data, 1987-2013. U.S. Department of Education, National Center for Education Statistics.

Conway, K., and Kimmel, J. (1998) Male Labor Supply Estimates and the Decision to Moonlight. Labour Economics, 5(2), 135-166.

Cooper, H., Nye, B., Charlton, K., Lindsay, J., and Greathouse, S. (1996). The Effects of Summer Vacation on Achievement Test Scores: A Narrative and Meta-Analytic Review. Review of Educational Research, 66(3): 227-268.

Daneshvary, N., and Clauretie, T. (2001). Efficiency and Costs in Education: Year-Round Versus Traditional Schedules. Economics of Education Review, 20(3): 279-287.

Dayton, K. (2015). For the Kids: California Voters Must Become Wary of Borrowing Billions More from Wealthy Investors for Educational Construction. California Policy Center.

Edgar, E., Spence, W., and Kenowitz, L. (1977). Extended School Year for the Handicapped: Is It Working? Journal of Special Education, 11(4): 441-447.

EdSource (2000). Local Bond Elections in California: Some Vital Statistics. Retrieved from https://edsource.org/wp-content/publications/bondhistory.pdf.

Frederiksen, A., Graversen, E., and Smith, N. (2008). Overtime Work, Dual Job Holding, and Taxation. Research in Labor Economics, 28:25-55.

Freeman, D. G. (1998). Determinants of Youth Suicide: The Easterlin-Hollinger Cohort Hypothesis Re-examined. American Journal of Economics and Sociology, 57(2): 183200.

Gandara, P., and Fish, J. (1994). Year-Round Schooling as an Avenue to Major Structural Reform. Educational Evaluation and Policy Analysis, 16(1): 67-85.

Graves, J. (2010). The Academic Impact of Multi-Track Year-Round School Calendars: A Response to School Overcrowding. Journal of Urban Economics, 67(3): 378-391. 
Graves, J., McMullen, S., and Rouse, K. (2013). Multi-track Year-Round Schooling as Cost Saving Reform: Not Just a Matter of Time. Education Finance and Policy, 8(3): 300-315.

Guariglia, A. and Kim, B. (2004) Earnings Uncertainty, Precautionary Saving and Moonlighting in Russia. Journal of Population Economics, 17(2): 289-310.

Guthrie, H. (1969) Teachers in the Moonlight. Monthly Labour Review, 92(2): 28-31

Hamel, H. (1967). Moonlighting - An Economic Phenomenon. Monthly Labor Review, 90(10): 17-23.

Hansen, B. (2008). School Year Length and Student Performance: Quasi-Experimental Evidence. Social Science Research Network Working Paper.

Hansen, B., and Lang, M. (2011). Back to School Blues: Seasonality of Youth Suicide and the Academic Calendar. Economics of Education Review, 30(5): 850-861.

Heineck, G., and Schwarze, J. (2004). Fly Me to the Moon: The Determinants of Secondary Jobholding in Germany and the U.K. IZA Discussion Paper No. 1358. Bonn, Germany: Institute for the Study of Labor.

Herman, J. (1991). Novel Approaches to Relieve Overcrowding: The Effects of Concept 6 YearRound Schools. Urban Education, 26(2), 195-213.

Heyns, B. (1987). Schooling and Cognitive Development: Is There a Season for Learning? Child Development, 58(5): 1151-1160.

Jacob, B., and Lefgren, L. (2003). Are Idle Hands the Devil's Workshop? Incapacitation, Concentration, and Juvenile Crime. American Economic Review. 93(5): 1560-1577.

Kimmel, J., and Conway, K. (2001) Who Moonlights and Why? Evidence from the SIPP. Industrial Relations, 40(1): 89-120.

Kimmel, J., and Powell, L. (1999). Moonlighting Trends and Related Policy Issues in Canada and The United States. Canadian Public Policy, 25(2): 207-231.

Krishnan, P. (1990) The Economics of Moonlighting: A Double Self-Selection Model. Review of Economics and Statistics, 72(2): 361-7.

Marcotte, D, and Hansen, B. (2010). Time for School? Education Next, 10(1): 52-59.

Marcotte, D., and Hemelt, S. (2008). Unscheduled School Closings and Student Performance. Education Finance and Policy, 3(3): 316-338. 
McMullen, S., and Rouse, K. (2012). The Impact of Year-Round Schooling on Academic Achievement: Evidence from Mandatory School Calendar Conversions. American Economic Journal, 4(4): 230-252.

McMullen, S., Rouse, K., and Haan, J (2015). The Distributional Effects of the Multi-Track Year-Round Calendar: A Quantile Regression Approach, Applied Economics Letters, 22:15, 1188-1192

Merino, B. (1983). The Impact of Year-Round Schooling: A Review. Urban Education, 18(3): 298-316.

Mitchell, R. (2002). Segregation In California’s K-12 Public Schools: Biases in Implementation, Assignments, and Achievement with the Multi-Track Year-Round Calendar. Report prepared for Williams et al. v. State of California et al., Superior Court, San Francisco, California.

Mitchell, R., and Mitchell, D. (2005). Student Segregation and Achievement Tracking in YearRound Schools. Teachers College Record, 107(4): 529-562.

O’Brien, D. (1999). Family and School Effects on the Cognitive Growth of Minority and Disadvantaged Elementary Students. Prepared for presentation to the American Education Finance Association.

Oakes, J. (1986). Keeping track: Part 1: The Policy and Practice of Curriculum Inequality. Phi Delta Kappan, 68(1), 12-17.

Patall, E., Cooper, H., and Allen, A. (2010). Extending the School Day or School Year: A Systematic Review of Research (1985-2009). Review of Educational Research, 80(3), 401-436

Panos, G., Pouliakas, K., and Zangelidis, A. (2011). Multiple Job Holding as a Strategy for Skills Diversification and Labour Market Mobility. Essex Business School, University of Essex.

Paxson, C., and Sicherman, N. (1996). The Dynamics of Dual Job Holding and Job Mobility. Journal of Labor Economics, 14(3); 357-393.

Perlman, R. (1966). Observations on Overtime and Moonlighting. Southern Economic Journal, 33(2): 237-244. 
Pischke, J. S. (2003). The Impact of Length of the School Year on Student Performance and Earnings: Evidence from the German Short School Year. NBER Working Paper Series. ISSN 0898-2937.

Ready, D., Lee, V. and Welner, K. (2004). Educational Equity and School Structure: School Size, Overcrowding, and Schools-Within-Schools. Teachers College Record 106(10): 1989-2014.

Renna, F. and Oaxaca, R. (2006) The Economics of Dual Job Holding: A Job Portfolio Model of Labor Supply. IZA Discussion Paper No. 1915. Bonn, Germany: Institute for the Study of Labor.

Renna, F., Oaxaca, R., and Choe, C. (2013). Constrained vs. Unconstrained Labor Supply: The Economics of Dual Job Holding. CEPS Instead Working Papers, Working Paper no. 2013-03.

Sargent, L., and Fidler, D. (1987). Extended School Year Programs: In Support of the Concept. Education and Training in Mental Retardation, 22(1): 3-9.

School Attendance Boundary Survey, 2010. U.S. Department of Education, National Center for Education Statistics.

School Calendar Data, 1998-2016. California Basic Educational Data System (CBEDS).

School Facility Program Data, 1998 - 2013. Office of Public School Construction, under the authority of the State of California's Department of General Services.

School Survey of the School and Staffing Survey, 1999, 2003, 2007, and 2011. U.S. Department of Education, National Center for Education Statistics.

School District General Obligation Bond Data, 1998-2015. Ed-Source.

Shishko, R., and Rostker, B. (1976). The Economics of Multiple Job Holding. American Economic Review, 66(3): 298-308.

Sims, D. (2008). Strategic Responses to School Accountability Measures: It's All in the Timing. Economics of Education Review, 27(1): 58-68.

U.S. Department of Education. (1997). What Do We Know: The Impact of the Baby Boom Echo. Washington, DC: U.S. Department of Education, Office of Educational Research and Improvement. 
U.S. Department of Education. (1999). A back to school special report on the baby boom echo: No end in sight. Washington, DC: Author, Office of Educational Research and Improvement.

Villagra, H. (2012). Ding, Dong, Concept 6 Is Dead. The Huffington Post. 29 Aug. 2012.

Von Hippel, P. (2016). Year-Round School Calendars: Effects on Summer Learning, Achievement, Parents, Teachers, and Property Values. Chapter for Handbook of Summer Learning (K. Alexander, ed.). New York: Teachers College Press. 
Figure 1: Average Number of Students and Teachers per School and Change in the Number of Schools
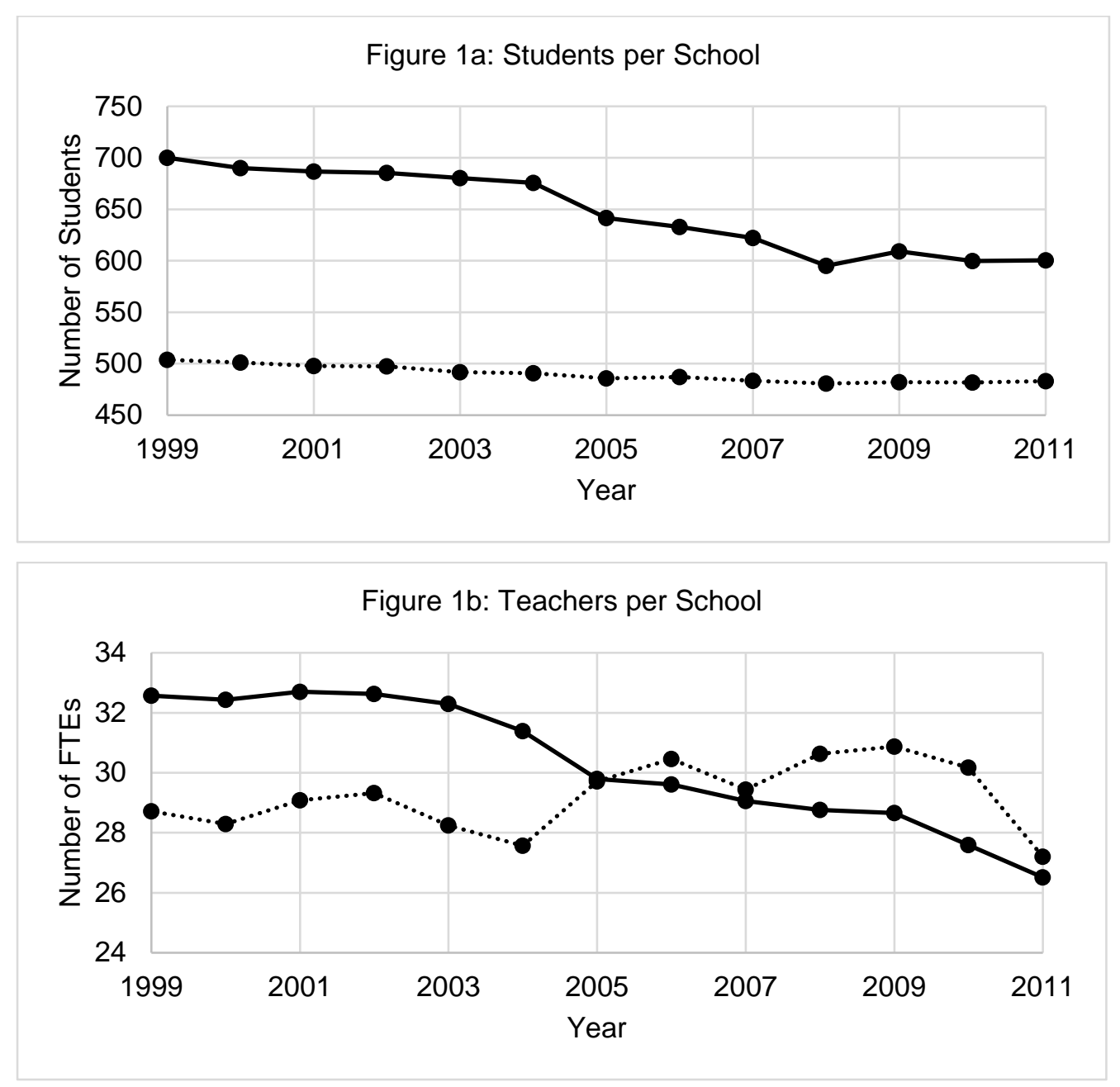

Figure 1c: Change in the Number of Schools

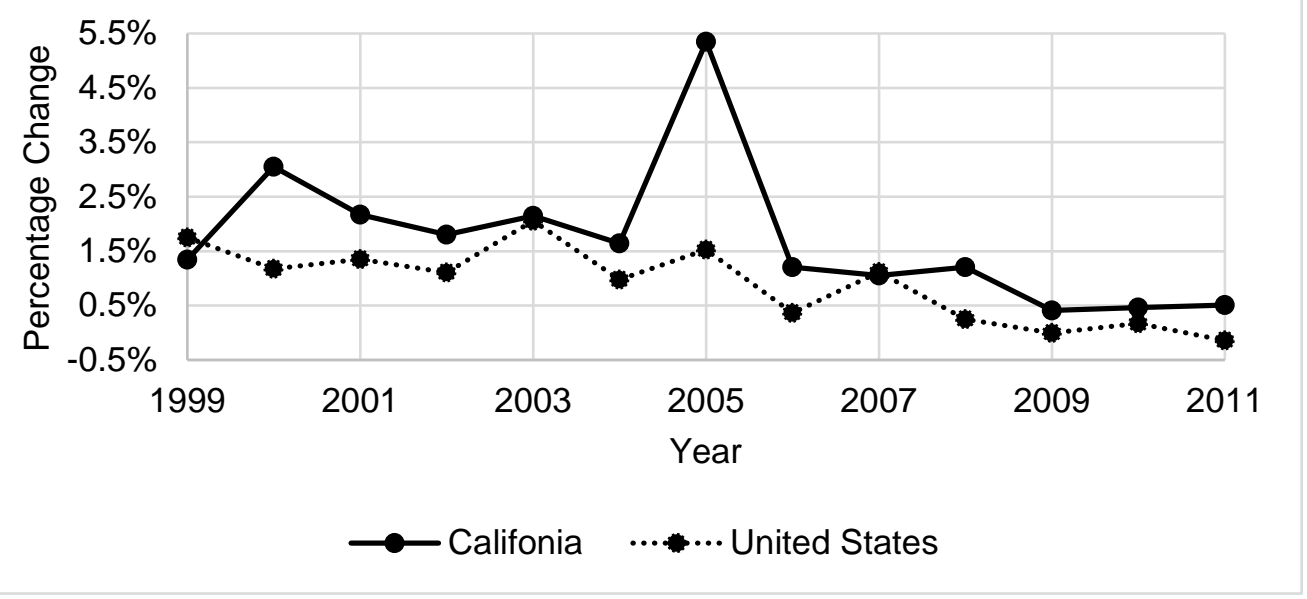

Note: FTE is defined as full-time teachers. Change in the number of schools equals the number of school openings minus school closures. Source: Common Core of Data, 1999-00 through 2011-12 school years. 
Figure 2: California Public School Calendar Conversions
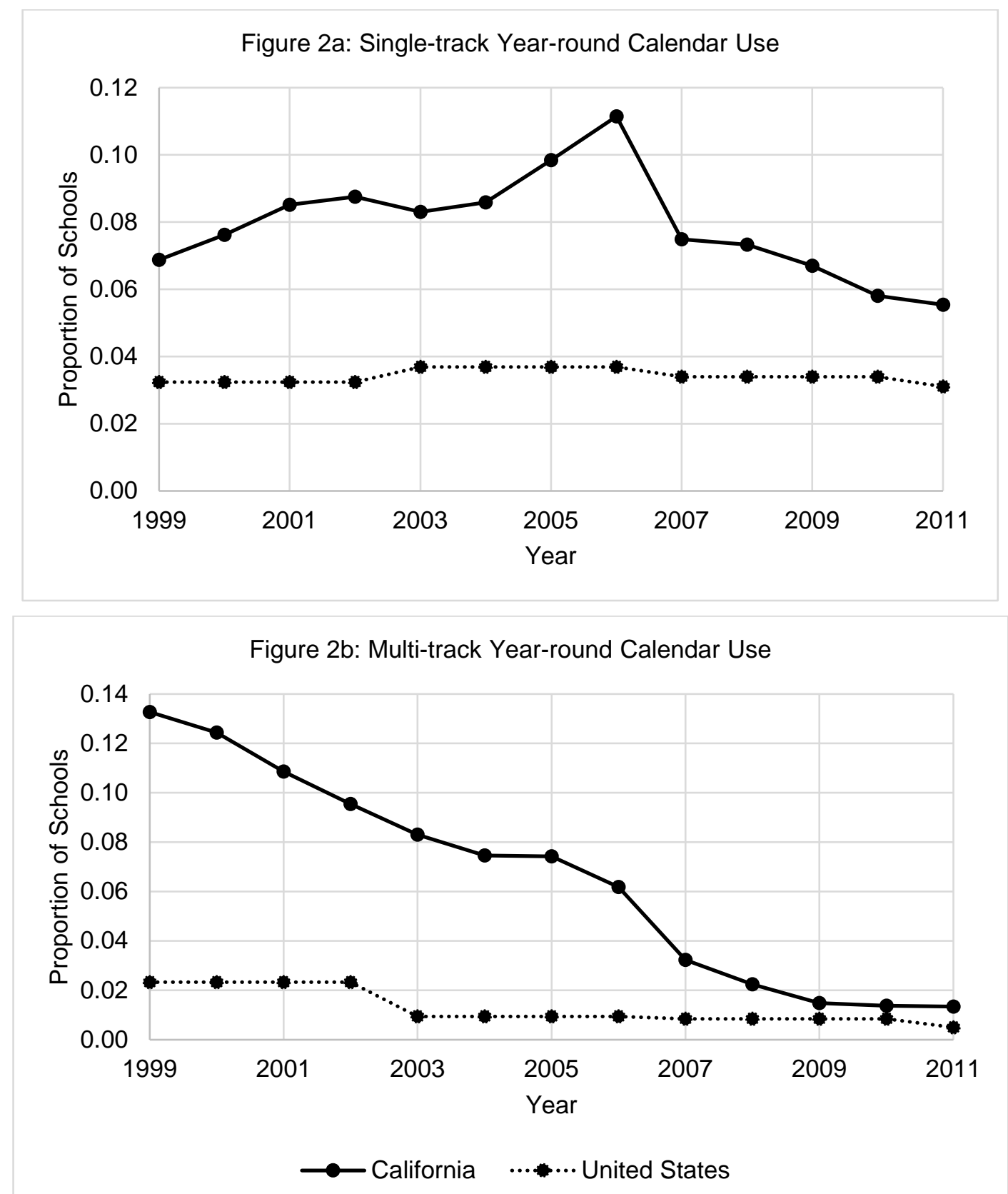

Note: Due to U.S. data limitations, changes in calendar use only changes when data survey is updated. The data suggest $11.7 \%$ of U.S. schools in 2007-08 school year were on a single-track year-round calendar. This is likely a data anomaly. The average from adjacent years is displayed instead. Source: California Basic Educational Data System (CBEDS) school-level data, 1999-00 through 2011-12 school years and Schools and Staffing Survey (1999-2000, 2003-04, 2007-08, and 2011-12). 
Figure 3: California Public School Multi-track Calendar Use by Outcome of Local School Construction Bond Vote

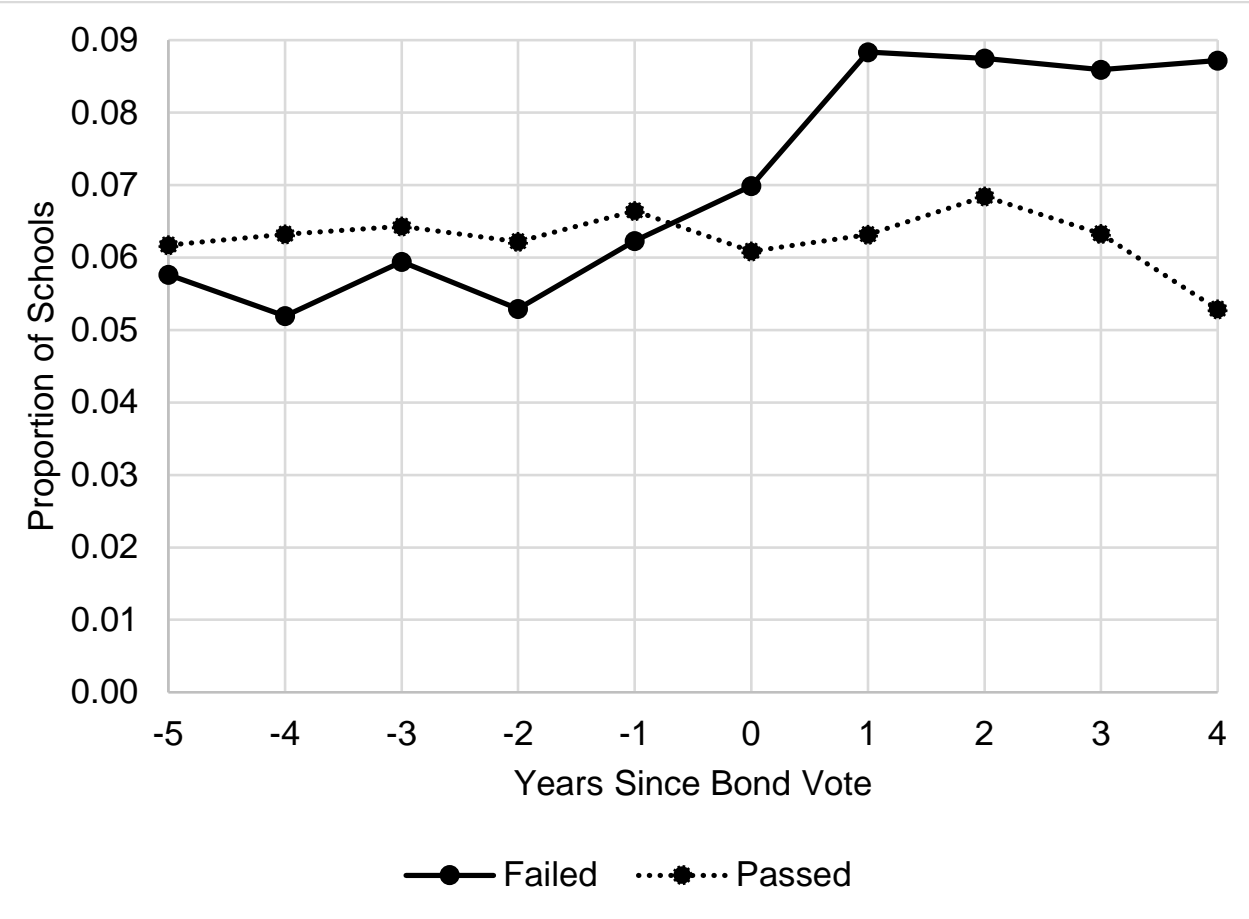

Note: School years 1999-00 through 2011-12 school years. Source: Calendar data provided by California Basic Educational Data System (CBEDS). General Obligation Bond data provided by Ed-Source. 


\section{Tables}

Table 1: Descriptive Statistics on Teachers' Secondary Employment Engagement

\begin{tabular}{lccccccc}
\hline & \multicolumn{3}{c}{ United States } & & \multicolumn{3}{c}{ California } \\
\cline { 2 - 3 } \cline { 6 - 8 } & All & Female & Male & & All & Female & Male \\
\hline School-based & $49.9 \%$ & $44.9 \%$ & $65.3 \%$ & & $52.0 \%$ & $48.2 \%$ & $61.9 \%$ \\
Non-school-based & $23.4 \%$ & $19.2 \%$ & $36.4 \%$ & & $17.3 \%$ & $14.2 \%$ & $25.2 \%$ \\
\hline Any & $58.9 \%$ & $53.2 \%$ & $76.5 \%$ & & $58.5 \%$ & $53.7 \%$ & $70.7 \%$ \\
\hline
\end{tabular}

Note: Weighted observations. Source: Author's calculations using the School Survey of the School and Staffing Survey (1999-2000, 2003-04, 2007-08, and 2011-12). 
Table 2: Number of California Schools and Average Duration on Calendar

\begin{tabular}{lccc}
\hline Number of & \multicolumn{3}{c}{ Years on Calendar } \\
\cline { 2 - 4 } Schools & $9-$-month & Single-track & Multi-track \\
\hline 5,274 & 13.0 & -- & -- \\
648 & 6.9 & 6.1 & -- \\
674 & 6.5 & -- & 6.6 \\
489 & 4.0 & 4.4 & 4.7 \\
\hline Note: Only includes public schools with complete school calendars information. Each row \\
sums to 13 school years. Source: Author's calculations using California Basic \\
Educational Data System (CBEDS) school-level data, 1999-00 through 2011-12 school \\
years.
\end{tabular}


Table 3: Summary statistics

\begin{tabular}{|c|c|c|c|c|}
\hline & Mean & Std. Dev. & Min & Max \\
\hline \multicolumn{5}{|l|}{ Dependent Variables } \\
\hline Engaged in secondary employment: 1 & 0.59 & -- & 0 & 1 \\
\hline Engaged in school-based secondary employment: 1 & 0.52 & -- & 0 & 1 \\
\hline Engaged in non-school-based secondary employment: 1 & 0.17 & -- & 0 & 1 \\
\hline \multicolumn{5}{|l|}{ Individual Characteristics } \\
\hline Female: 1 & 0.72 & -- & 0 & 1 \\
\hline Non-white: 1 & 0.29 & -- & 0 & 1 \\
\hline Age & 44.3 & 11.4 & 20.0 & 88.0 \\
\hline Bachelor's degree within California: 1 & 0.73 & -- & 0 & 1 \\
\hline $\log ($ Primary job earnings) & $\$ 11.0$ & $\$ 0.3$ & $\$ 6.9$ & $\$ 12.3$ \\
\hline \multicolumn{5}{|l|}{ School/Student Body Characteristics } \\
\hline Individual Education Plan (\%) & 8.9 & 8.3 & 0 & 100 \\
\hline Eligible for free lunch (\%) & 44.3 & 33.8 & 0 & 100 \\
\hline Minority (\%) & 62.9 & 28.9 & 0 & 100 \\
\hline Combined school: 1 & 0.02 & -- & 0 & 1 \\
\hline Secondary school: 1 & 0.31 & -- & 0 & 1 \\
\hline Year-round calendar: 1 & 0.13 & -- & 0 & 1 \\
\hline Single-track calendar: 1 & 0.07 & -- & 0 & 1 \\
\hline Multi-track calendar: 1 & 0.06 & -- & 0 & 1 \\
\hline \multicolumn{5}{|l|}{ Community Characteristics } \\
\hline Rural: 1 & 0.04 & -- & 0 & 1 \\
\hline Metropolitan: 1 & 0.42 & -- & 0 & 1 \\
\hline Local education funds (\%) & 45.3 & 26.7 & 0 & 100 \\
\hline Local area unemployment (\%) & 7.9 & 3.9 & 2.0 & 29.7 \\
\hline Local area wage gap ${ }^{b}$ & $-\$ 0.4$ & $\$ 0.4$ & $-\$ 1.6$ & $\$ 3.5$ \\
\hline Population growth & 1.2 & 0.9 & -1.0 & 4.7 \\
\hline Teacher Observations $^{c}$ & \multicolumn{4}{|c|}{4,490} \\
\hline
\end{tabular}

Notes: Sampling weights applied. All amounts in 2012 dollars. a: Primary job earnings includes salary, state supplemental, performance-based compensation, and bonuses as a full-time teacher. Local area wage gap is the difference between log per capita average local income and log of the teacher's salary. All binary variables omit standard deviations. Observations rounded to the nearest 10 s are per data license restriction. 
Table 4: Descriptive Statistics on Teachers' Primary Employment Characteristics

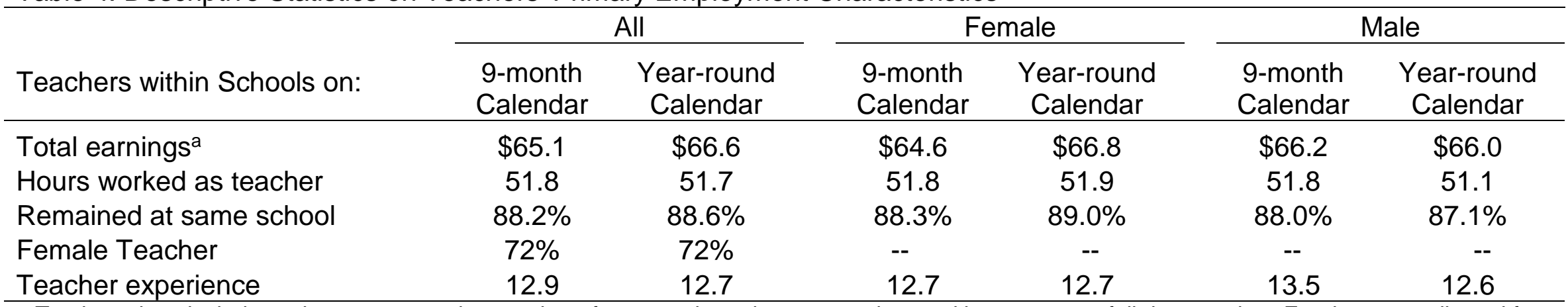

a:Total earnings includes salary, state supplemental, performance-based compensation, and bonuses as a full-time teacher. Earnings not adjusted for teacher experience. Sampling weights applied. All amounts in $\$ 10,000$ s of 2012 dollars. ${ }^{\star} p<0.1,{ }^{* \star} p<0.05,{ }^{* \star} p<0.01$ 
Table 5: Proportion of Teachers Currently Engaged in Secondary Employment, By School Calendar Conversion

\begin{tabular}{lccc}
\hline & $\begin{array}{c}\text { School Never on } \\
\text { Year-round Calendar }\end{array}$ & $\begin{array}{c}\text { School on Year- } \\
\text { round Calendar }\end{array}$ & $\begin{array}{c}\text { School switched to 9- } \\
\text { month Calendar }\end{array}$ \\
\hline School-based SE & $55.6 \%$ & $77.3 \%$ & $41.0 \%$ \\
Non-school-based SE & $19.9 \%$ & $18.2 \%$ & $16.2 \%$ \\
\hline Any & $62.8 \%$ & $81.8 \%$ & $47.6 \%$ \\
\hline Source: Author's calculations using the School Survey of the School and Staffing Survey (1999-2000, 2003- \\
04, 2007-08, and 2011-12). Note: Weighted observations. All amounts in 2012 dollars.
\end{tabular}


Table 6: Main Estimation Results

\begin{tabular}{|c|c|c|c|c|c|c|}
\hline & \multicolumn{2}{|c|}{ All SE } & \multicolumn{2}{|c|}{ School-based SE } & \multicolumn{2}{|c|}{ Non-school-based SE } \\
\hline & Coeff. & Std. Err. & Coeff. & Std. Err. & Coeff. & Std. Err. \\
\hline Female & -0.230 & 0.293 & -0.274 & 0.294 & -0.389 & 0.267 \\
\hline Non-white & 0.047 & 0.060 & 0.061 & 0.063 & -0.003 & 0.046 \\
\hline Age & -0.003 & 0.013 & -0.003 & 0.013 & $-0.024 * \star$ & 0.011 \\
\hline $\mathrm{Age}^{2}$ & 0.000 & 0.000 & 0.000 & 0.000 & $0.000^{*}$ & 0.000 \\
\hline Age $\times$ Female & 0.006 & 0.014 & 0.009 & 0.014 & 0.013 & 0.012 \\
\hline $\mathrm{Age}^{2} \times$ Female & 0.000 & 0.000 & 0.000 & 0.000 & 0.000 & 0.000 \\
\hline BA degree within state & -0.024 & 0.024 & -0.008 & 0.025 & -0.019 & 0.017 \\
\hline log(total teacher salary) & $0.173^{*}$ & 0.095 & $0.191^{\star \star}$ & 0.093 & 0.083 & 0.073 \\
\hline Individual education plan & $-0.002^{*}$ & 0.001 & -0.002 & 0.001 & $-0.001^{\star}$ & 0.001 \\
\hline Eligible for free lunch & $0.001^{*}$ & 0.001 & 0.001 & 0.001 & 0.001 & 0.000 \\
\hline Minority & -0.001 & 0.001 & -0.001 & 0.001 & $-0.001^{\star *}$ & 0.000 \\
\hline Combined school & 0.041 & 0.057 & -0.034 & 0.063 & $0.117^{* \star}$ & 0.055 \\
\hline Secondary school & $0.155^{\star \star \star}$ & 0.023 & $0.161^{\star \star *}$ & 0.024 & $0.072^{\star \star \star}$ & 0.021 \\
\hline Non-white $\mathrm{X}$ minority & -0.001 & 0.001 & -0.001 & 0.001 & 0.000 & 0.001 \\
\hline Rural & -0.026 & 0.056 & -0.049 & 0.056 & 0.022 & 0.041 \\
\hline Metropolitan & 0.022 & 0.028 & 0.025 & 0.026 & -0.008 & 0.017 \\
\hline Local education funds & 0.000 & 0.001 & 0.000 & 0.001 & 0.000 & 0.000 \\
\hline Local area unemployment & -0.008 & 0.006 & -0.004 & 0.006 & -0.003 & 0.004 \\
\hline Local area wage gap & 0.024 & 0.085 & 0.026 & 0.080 & 0.048 & 0.068 \\
\hline Population Growth & 0.010 & 0.016 & 0.002 & 0.017 & 0.008 & 0.012 \\
\hline Year-round Calendar & $0.138^{\star *}$ & 0.061 & $0.180^{\star * *}$ & 0.047 & -0.030 & 0.040 \\
\hline District Fixed Effects & \multicolumn{2}{|c|}{ Yes } & \multicolumn{2}{|c|}{ Yes } & \multicolumn{2}{|c|}{ Yes } \\
\hline Year Fixed Effects & \multicolumn{2}{|c|}{ Yes } & \multicolumn{2}{|c|}{ Yes } & \multicolumn{2}{|c|}{ Yes } \\
\hline Observations & \multicolumn{2}{|c|}{4,490} & \multicolumn{2}{|c|}{4,490} & \multicolumn{2}{|c|}{4,490} \\
\hline $\mathrm{R}^{2}$ & \multicolumn{2}{|c|}{0.18} & \multicolumn{2}{|c|}{0.19} & \multicolumn{2}{|c|}{0.14} \\
\hline
\end{tabular}

Notes: Weighted regressions. District-level cluster robust standard errors. ${ }^{*} p<0.1,{ }^{\star \star} p<0.05, p$ $<0.001$. Observations rounded to the nearest 10 s are per data license restriction. 
Table 7: Year-round Calendar Coefficient Sensitivity Analysis

All SE

\begin{tabular}{lcccccc}
\hline & Model 1 & Model 2 & Model 3 & Model 4 & Model 5 & Model 6 \\
\hline Coefficient & $0.154^{\star *}$ & $0.137^{\star *}$ & $0.140^{\star *}$ & $0.133^{\star *}$ & $0.142^{\star *}$ & $0.137^{\star *}$ \\
Standard Error & 0.067 & 0.064 & 0.060 & 0.062 & 0.066 & 0.061 \\
\hline Observations & 4,540 & 4,540 & 4,540 & 4,540 & 4,490 & 4,490 \\
$\mathrm{R}^{2}$ & 0.13 & 0.13 & 0.17 & 0.15 & 0.13 & 0.18 \\
\hline
\end{tabular}

School-based SE

\begin{tabular}{lcccccc}
\hline & Model 1 & Model 2 & Model 3 & Model 4 & Model 5 & Model 6 \\
\hline Coefficient & $0.195^{\star \star \star}$ & $0.180^{\star * *}$ & $0.183^{\star \star *}$ & $0.179^{\star \star *}$ & $0.183^{\star \star *}$ & $0.180^{\star \star *}$ \\
Standard Error & 0.055 & 0.052 & 0.048 & 0.049 & 0.052 & 0.047 \\
\hline Observations & 4,540 & 4,540 & 4,540 & 4,540 & 4,490 & 4,490 \\
$\mathrm{R}^{2}$ & 0.14 & 0.14 & 0.17 & 0.16 & 0.14 & 0.19 \\
\hline
\end{tabular}

Non-school-based SE

\begin{tabular}{lcccccc}
\hline & Model 1 & Model 2 & Model 3 & Model 4 & Model 5 & Model 6 \\
\hline Coefficient & -0.000 & -0.027 & -0.027 & -0.034 & -0.021 & -0.030 \\
Standard Error & 0.044 & 0.042 & 0.040 & 0.042 & 0.042 & 0.041 \\
\hline Observations & 4,540 & 4,540 & 4,540 & 4,540 & 4,490 & 4,490 \\
$\mathrm{R}^{2}$ & 0.11 & 0.11 & 0.13 & 0.12 & 0.11 & 0.14 \\
\hline & & & & & & \\
\hline Covariates included: & & & & & & \\
$\quad$ District Fixed Effects & Yes & Yes & Yes & Yes & Yes & Yes \\
Year Fixed Effects & No & Yes & Yes & Yes & Yes & Yes \\
Teacher & No & No & Yes & No & No & Yes \\
School & No & No & No & Yes & No & Yes \\
Community & No & No & No & No & Yes & Yes \\
\hline
\end{tabular}

Notes: Each row and column represents a separate regression and only the coefficient estimate and standard error on calendar conversion variable is displayed along with the observation count and $\mathrm{R}^{2}$. Total of 18 regressions. District-level cluster robust standard errors. ${ }^{*} p<0.1,{ }^{*} p<0.05, p<0.001$. Observations rounded to the nearest 10 s are per data license restriction. Sampling weights applied. 
Table 8: Estimation Results by Teacher Characteristics

All SE

\begin{tabular}{lccccccc}
\hline & \multirow{2}{*}{ Female } & \multirow{2}{*}{ Male } & \multicolumn{3}{c}{ Age } & \multirow{2}{*}{ Elementary } & \multirow{2}{*}{ Secondary } \\
\cline { 4 - 6 } & & & $<30$ & $30-39$ & $40+$ & & \\
\hline Coefficient & 0.109 & $0.253^{\star * *}$ & 0.157 & $0.250^{\star \star}$ & $0.162^{\star *}$ & 0.075 & 0.166 \\
Standard Error & 0.083 & 0.08 & 0.142 & 0.104 & 0.067 & 0.108 & 0.117 \\
\hline Observations & 2,970 & 1,520 & 610 & 1,190 & 2,690 & 2,240 & 2,250 \\
$\mathrm{R}^{2}$ & 0.21 & 0.34 & 0.46 & 0.43 & 0.25 & 0.24 & 0.17 \\
\hline
\end{tabular}

School-based SE

\begin{tabular}{lccccccc}
\hline & \multirow{2}{*}{ Female } & \multirow{2}{*}{ Male } & \multicolumn{3}{c}{ Age } & \multirow{2}{*}{ Elementary } & \multirow{2}{*}{ Secondary } \\
\cline { 4 - 6 } & & & $<30$ & $30-39$ & $40+$ & & \\
\hline Coefficient & $0.145^{\star \star}$ & $0.337^{\star \star \star}$ & 0.072 & $0.258^{\star \star}$ & $0.197^{\star \star \star}$ & $0.138^{\star}$ & $0.201^{\star}$ \\
Standard Error & 0.062 & 0.064 & 0.185 & 0.106 & 0.055 & 0.083 & 0.118 \\
\hline Observations & 2,970 & 1,520 & 610 & 1,190 & 2,690 & 2,240 & 2,250 \\
$\mathrm{R}^{2}$ & 0.22 & 0.33 & 0.46 & 0.42 & 0.26 & 0.25 & 0.16 \\
\hline
\end{tabular}

Non-school-based SE

\begin{tabular}{lccccccc}
\hline & \multirow{2}{*}{ Female } & \multirow{2}{*}{ Male } & \multicolumn{3}{c}{ Age } & \multirow{2}{*}{ Elementary } & \multirow{2}{*}{ Secondary } \\
\cline { 4 - 5 } & & & $<30$ & $30-39$ & $40+$ & & \\
\hline Coefficient & -0.055 & -0.019 & 0.239 & 0.012 & -0.02 & -0.041 & -0.044 \\
Standard Error & 0.056 & 0.099 & 0.269 & 0.068 & 0.048 & 0.071 & 0.105 \\
\hline Observations & 2,970 & 1,520 & 610 & 1,190 & 2,690 & 2,240 & 2,250 \\
$\mathrm{R}^{2}$ & 0.18 & 0.29 & 0.50 & 0.36 & 0.21 & 0.21 & 0.13 \\
\hline
\end{tabular}

Notes: Each row and column represents a separate regression and only the coefficient estimate and standard errors on calendar conversion variable is displayed along with the observation count and $\mathrm{R}^{2}$. Total of 21 regressions. All regressions include district and year fixed effects as well as teacher, school, and community covariates. Sampling weights applied. District-level cluster robust standard errors. ${ }^{*} p<0.1$, ${ }^{\star *} p<0.05, p<0.001$. Observations rounded to the nearest 10 s are per data license restriction. 
Table 9: Estimation Results by Type and Timing of Calendar Conversion

Table 9a: Proximity to School with Different Calendar

\begin{tabular}{|c|c|c|c|c|c|c|}
\hline & \multicolumn{2}{|c|}{ All SE } & \multicolumn{2}{|c|}{ School-based SE } & \multicolumn{2}{|c|}{ Non-school-based SE } \\
\hline & Coeff. & Std. Err. & Coeff. & Std. Err. & Coeff. & Std. Err. \\
\hline One School in District on Year-round Calendar & -0.029 & 0.020 & -0.021 & 0.021 & -0.010 & 0.013 \\
\hline Observations & \multicolumn{2}{|c|}{5,600} & \multicolumn{2}{|c|}{5,600} & \multicolumn{2}{|c|}{5,600} \\
\hline $\mathrm{R}^{2}$ & \multicolumn{2}{|c|}{0.07} & \multicolumn{2}{|c|}{0.06} & \multicolumn{2}{|c|}{0.04} \\
\hline
\end{tabular}

Table 9b: Type of Calendar

\begin{tabular}{|c|c|c|c|c|c|c|}
\hline & \multicolumn{2}{|c|}{ All SE } & \multicolumn{2}{|c|}{ School-based SE } & \multicolumn{2}{|c|}{ Non-school-based SE } \\
\hline & Coeff. & Std. Err. & Coeff. & Std. Err. & Coeff. & Std. Err. \\
\hline Single-track Year-round & -0.045 & 0.077 & -0.028 & 0.067 & -0.023 & 0.041 \\
\hline Concept 6 (3-track) & $0.245^{\star}$ & 0.127 & $0.337^{* * *}$ & 0.100 & -0.041 & 0.061 \\
\hline 4-5 track & $0.304^{\star \star \star}$ & 0.100 & $0.352^{\star \star *}$ & 0.089 & -0.019 & 0.046 \\
\hline Observations & \multicolumn{2}{|c|}{4,490} & \multicolumn{2}{|c|}{4,490} & \multicolumn{2}{|c|}{4,490} \\
\hline $\mathrm{R}^{2}$ & \multicolumn{2}{|c|}{0.18} & \multicolumn{2}{|c|}{0.19} & \multicolumn{2}{|c|}{0.14} \\
\hline
\end{tabular}

Table 9c: Timing of calendar change ${ }^{\mathrm{a}}$

\begin{tabular}{|c|c|c|c|c|c|c|}
\hline & \multicolumn{2}{|c|}{ All SE } & \multicolumn{2}{|c|}{ School-based SE } & \multicolumn{2}{|c|}{ Non-school-based SE } \\
\hline & Coeff. & Std. Err. & Coeff. & Std. Err. & Coeff. & Std. Err. \\
\hline Two years prior to year-round calendar change & -0.006 & 0.075 & 0.014 & 0.079 & -0.043 & 0.039 \\
\hline Year-round calendar change & $0.139 * *$ & 0.060 & $0.182^{\star \star \star}$ & 0.047 & 0.029 & 0.040 \\
\hline One year after year-round calendar change & $0.138 * *$ & 0.061 & $0.180 * \star \star$ & 0.047 & 0.062 & 0.040 \\
\hline Two years after year-round calendar change & $0.216^{*}$ & 0.0129 & $0.302^{\star \star}$ & 0.119 & 0.008 & 0.085 \\
\hline Observations & \multicolumn{2}{|c|}{2,870} & \multicolumn{2}{|c|}{2,870} & \multicolumn{2}{|c|}{2,870} \\
\hline $\mathrm{R}^{2}$ & \multicolumn{2}{|c|}{0.22} & \multicolumn{2}{|c|}{0.23} & \multicolumn{2}{|c|}{0.16} \\
\hline
\end{tabular}

Notes: Each row and column represents a separate regression and only the coefficient estimates and standard errors on calendar conversion variables are displayed. Total of 9 regressions. District-level cluster robust standard errors. ${ }^{\star} p<0.1,{ }^{\star \star} p<0.05, p<0.001$. a: District fixed effects omitted due to collinearity with district-level year-round calendar binary variable. Omitted category is one year prior to calendar change. 


\section{Appendix A: Year-round calendar background and literature}

School calendars have traditionally been organized with 180 school days spread over 9-months with a few smaller breaks and a longer summer break. There have been significant calendar modifications, typically initiated at the school or district level. Calendar modifications include changes to the total number of school days per year, number of instructional days per week, length of school day, and the school break spacing. A year-round calendar conversion spreads the total number of mandated instructional days over 12 months by cutting the summer break into smaller, more frequent breaks. During conversion, schools must also decide whether all students and teachers take breaks at the same time (single-track), or rotate on tracks (multi-track). Traditional 9-month calendars are single track and provide fixed capacity while multi-track year-round calendars permit school buildings to be continuously utilized, increasing building capacity and efficiency. See Coleman and Freehorn (1993) for a discussion on the mechanics of year-round calendars.

Table A.1 provides a descriptive overview of U.S. public school calendar use during 19992000 through 2011-2012 school years. On average, 6.6\% of U.S. public schools use a year-round calendar during this period with a substantial spike in use during the mid-2000s. Single track yearround calendar use rose from approximately 3.3\% of all U.S. public schools in 1999-2000 school year to $11.7 \%$ in the $2007-08$ school year and then fell to $3.1 \%$ during the $2011-12$ school year. Use of multi-track year-round calendars trended downward from 2.3\% of all U.S. public schools in 1999-2000 to $0.5 \%$ during 2011-12 school year. ${ }^{18}$ While all states have schools on year-round calendars, states with warmer climates tend to have higher proportions: California (10.5\%), Hawaii (7.0\%), Arizona (4.2\%), and Nevada (4.0\%). In addition, California has the highest use of multitrack schooling (45.6\% of all year-round schools during 1999-00 through 2011-12 school years). While many California schools deployed year-round calendars, they did so for 4 to 6 years (see Table 2), suggesting that year-round calendar use was a stopgap.

There are several reasons why schools choose to convert to a year-round calendar. Researchers examining school expenditure data find that year-round schooling can be more cost effective (see Merino (1983), Coleman and Freehorn (1993), Daneshvary and Clauretie (2001), Gandara and Fish (2004), and Graves, McMullen, and Rouse (2013)). For example, a four-track

\footnotetext{
18 There is some concern whether the 2007-08 spike in the national single-track year-round calendar use is a data anomaly.
} 
year-round calendar extends the capacity of the school by 33\%, e.g., a school with the capacity for 750 students can accommodate 1,000 students with three tracks of 250 student 'in school' and one track 'on vacation' at any given time. Merino (1983) finds that year-round schooling results in cost savings for both schools and families. When vacation time is split more evenly throughout the school year, families incur lower costs associated with recreation and vacation activities. However, Graves, McMullen, and Rouse (2013) show that the cost effectiveness of year-round programs varies with facility capacity utilization and that the greatest benefits are realized by schools suffering from high levels of overcrowding when they deploy the multi-track year-round school calendar. Similarly, Coleman and Freehorn (1993) find that year-round schooling is only costeffective when the student population exceeds $115 \%$ of the school's capacity. Anecdotally, yearround calendars may be preferred in warmer climates so that children are in air-conditioned classrooms during the extremely hot summer months and on break during more pleasant climates.

Research has identified several potential learning losses during summer vacation (Allinder, Fuchs, and Hamlett (1992), Heyns (1987), O’Brien (1999), Cooper et al. (1996), and Alexander, Entwisle, and Olson (2007)). Results relating to the impacts of year-round schooling on student academic performance are mixed (see Patall et al. (2010) for a review of research from 19852009). McMullen and Rouse (2012) find that the academic achievement of the average student is not affected by a conversion from a 9-month calendar to a year-round calendar. Graves (2010) and Graves, McMullen, and Rouse (2013) find that year-round schooling may have negative effects on academic achievement and highlight the impacts of year-round schooling will vary across schools that face different student body compositions, such as those with higher proportions of minorities, students in low socioeconomic families, and English as a second language (ESL) students. McMullen and Rouse (2012) find that no particular racial subgroup benefits more than others from year-round schooling, while McMullen et al. (2015) find positive impacts for the lowest-performing students. Cooper et al. (2003) find significant benefits to year-round schooling for economically disadvantaged students, and Edgar, Spence, and Kenowitz (1977) and Sargent and Fidler (1987) find that students with learning disabilities benefit from year-round schooling. The effects of calendar conversion also vary by type of year-round calendar. Graves (2010) estimates that national academic achievement percentile rankings for schools who convert to yearround calendars drop between $1 \%-2 \%$ with estimates varying significantly between single- and 
multi- tracking. Mitchell and Mitchell (2005) find large disparities in student achievement between tracks within multi-track calendar schools.

Conversion to year-round schooling may impact students' behavior as well. Freeman (1998) examines the effect of adolescent cohort size on youth suicide using the percentage of the U.S. population between 15 and 19 years of age to represent the adolescent cohort. ${ }^{19}$ The study finds a positive and statistically significant effect on youth adolescent suicide rates from multitrack calendars. However, Hansen and Lang (2011) find a significant decrease in the incidence of youth suicide when school is not in session, suggesting that year-round schooling may increase youth stress and decrease mental health. Other research focuses on the impacts of being in school on the incidence of adolescent crime. Jacob and Lefgren (2003) examine the tradeoff between types of adolescent crime committed when school is and is not in session. The authors find that the incidence of adolescent property crime decreases by 14 percent when school is in session, but that violent crime increases by 28 percent. They indicate that schools provide monitoring, structure, and activities that lead to a reduction in property crime. However, adolescent interaction is amplified when school is in session, thereby leading to an increase in the number of violent crimes. Von Hippel, P. (2016) provides an overview of research regarding year-round schooling and the effect on students, parents, teachers, and property values.

In the broader school calendar change literature, multiple studies focus on how changes in the total number of school days and school start date affects student performance and academic achievement (see Marcotte and Hemelt (2008), Oakes (1986), Pischke (2003), Marcotte and Hansen (2010), Sims (2008), Gandara and Fish (2004) and Hansen (2008)).

19 Freeman (1998) asserts that the proportion of the adolescent population measures the "competition among the cohort for employment, school placement, [and] athletic recognition..." 
Table A1: National Statistics on Year-round Calendar and Track Use

\begin{tabular}{|c|c|c|c|c|c|c|c|c|}
\hline \multirow[t]{2}{*}{ State } & \multicolumn{4}{|c|}{$\begin{array}{l}\text { Percent of Public School } \\
\text { on Year-round Calendar }\end{array}$} & \multicolumn{4}{|c|}{$\begin{array}{c}\text { Percent of Public Schools on } \\
\text { Year-round Calendars using Multi-track }\end{array}$} \\
\hline & $1999-00$ & $2003-04$ & $2007-08$ & 2011-12 & $1999-00$ & 2003-04 & $2007-08$ & 2011-12 \\
\hline Alabama & 5.5 & 5.7 & 15.1 & 2.9 & 0.0 & 0.0 & 14.1 & 0.0 \\
\hline Alaska & 2.2 & 2.7 & 12.0 & 0.0 & 0.0 & 0.0 & 0.0 & 0.0 \\
\hline Arizona & 16.9 & 7.1 & 12.5 & 4.5 & 0.0 & 0.0 & 0.0 & 0.0 \\
\hline Arkansas & 1.9 & 3.0 & 16.1 & 2.8 & 0.0 & 0.0 & 0.0 & 11.3 \\
\hline California & 22.9 & 13.9 & 21.9 & 5.5 & 84.0 & 44.4 & 23.1 & 8.3 \\
\hline Colorado & 5.6 & 6.0 & 13.8 & 1.8 & 69.2 & 57.8 & 26.0 & 0.0 \\
\hline Connecticut & 2.9 & 3.9 & 8.4 & 5.4 & 0.0 & 0.0 & 0.0 & 27.5 \\
\hline Delaware & 7.1 & 1.4 & 11.3 & 0.0 & 0.0 & 0.0 & 0.0 & 0.0 \\
\hline District of Columbia & 15.5 & 16.0 & 24.4 & 3.7 & 0.0 & 0.0 & 0.0 & 0.0 \\
\hline Florida & 1.2 & 4.8 & 9.0 & 1.2 & 94.6 & 34.5 & 0.0 & 13.6 \\
\hline Georgia & 1.0 & 4.7 & 16.2 & 4.5 & 100.0 & 0.0 & 0.0 & 32.4 \\
\hline Hawaii & 36.6 & 44.1 & 51.6 & 8.2 & 0.0 & 2.7 & 2.3 & 9.6 \\
\hline Idaho & 2.8 & 2.7 & 9.9 & 0.3 & 42.4 & 20.4 & 9.2 & 0.0 \\
\hline Illinois & 5.4 & 1.7 & 11.2 & 2.3 & 23.4 & 0.0 & 1.4 & 38.8 \\
\hline Indiana & 1.1 & 1.7 & 7.5 & 2.5 & 0.0 & 0.0 & 0.0 & 0.0 \\
\hline Iowa & 1.5 & 0.0 & 13.7 & 0.4 & 0.0 & 0.0 & 0.0 & 0.0 \\
\hline Kansas & 3.9 & 0.9 & 4.8 & 1.6 & 0.0 & 0.0 & 0.0 & 0.0 \\
\hline Kentucky & 12.0 & 10.2 & 21.1 & 1.1 & 0.0 & 0.0 & 0.0 & 0.0 \\
\hline Louisiana & 5.6 & 6.8 & 7.8 & 4.5 & 0.0 & 0.0 & 0.0 & 0.0 \\
\hline Maine & 1.8 & 1.0 & 11.1 & 2.6 & 0.0 & 0.0 & 0.0 & 0.0 \\
\hline Maryland & 4.0 & 4.1 & 9.3 & 4.8 & 0.0 & 0.0 & 27.1 & 0.0 \\
\hline Massachusetts & 3.4 & 1.6 & 8.6 & 3.9 & 0.0 & 0.0 & 0.0 & 0.0 \\
\hline Michigan & 6.5 & 3.4 & 10.1 & 2.5 & 0.0 & 0.0 & 0.0 & 20.5 \\
\hline Minnesota & 0.3 & 0.7 & 13.6 & 2.8 & 0.0 & 0.0 & 0.0 & 0.0 \\
\hline Mississippi & 4.8 & 2.4 & 10.0 & 5.6 & 0.0 & 0.0 & 0.0 & 9.5 \\
\hline Missouri & 4.5 & 2.7 & 10.2 & 1.7 & 35.1 & 0.0 & 0.0 & 0.0 \\
\hline Montana & 2.3 & 5.3 & 8.1 & 4.3 & 0.0 & 0.0 & 0.0 & 0.0 \\
\hline Nebraska & 2.7 & 0.7 & 10.9 & 3.1 & 30.5 & 0.0 & 0.0 & 42.6 \\
\hline Nevada & 26.8 & 14.9 & 25.9 & 3.5 & 67.4 & 85.9 & 49.3 & 0.0 \\
\hline New Hampshire & 3.5 & 0.0 & 8.0 & 1.9 & 0.0 & 0.0 & 25.5 & 0.0 \\
\hline New Jersey & 3.7 & 2.3 & 11.9 & 5.3 & 0.0 & 28.7 & 0.0 & 3.0 \\
\hline New Mexico & 6.6 & 3.0 & 12.8 & 6.4 & 0.0 & 0.0 & 9.4 & 0.0 \\
\hline New York & 4.0 & 4.3 & 9.0 & 8.1 & 0.0 & 0.0 & 3.2 & 12.4 \\
\hline North Carolina & 7.2 & 3.9 & 13.9 & 2.8 & 51.7 & 20.8 & 0.0 & 26.9 \\
\hline North Dakota & 1.3 & 0.4 & 10.7 & 1.5 & 0.0 & 0.0 & 0.0 & 0.0 \\
\hline Ohio & 1.0 & 2.5 & 8.9 & 1.6 & 0.0 & 0.0 & 0.0 & 12.5 \\
\hline Oklahoma & 4.4 & 2.9 & 8.3 & 9.8 & 15.5 & 0.0 & 0.0 & 12.8 \\
\hline Oregon & 2.5 & 1.5 & 6.7 & 1.1 & 0.0 & 0.0 & 0.0 & 0.0 \\
\hline Pennsylvania & 0.0 & 3.5 & 10.7 & 3.4 & 0.0 & 35.9 & 0.0 & 0.0 \\
\hline Rhode Island & 4.4 & 1.9 & 16.3 & 5.7 & 0.0 & 0.0 & 38.7 & 31.2 \\
\hline South Carolina & 2.0 & 6.0 & 11.7 & 4.6 & 0.0 & 0.0 & 0.0 & 52.8 \\
\hline South Dakota & 0.0 & 0.5 & 6.5 & 2.0 & 0.0 & 0.0 & 0.0 & 100.0 \\
\hline Tennessee & 5.4 & 5.6 & 14.0 & 0.9 & 37.1 & 0.0 & 0.0 & 0.0 \\
\hline Texas & 3.8 & 4.6 & 13.3 & 4.3 & 12.3 & 2.1 & 2.2 & 0.0 \\
\hline Utah & 11.0 & 6.7 & 21.3 & 5.5 & 97.7 & 61.9 & 27.7 & 62.8 \\
\hline Vermont & 0.0 & 1.1 & 6.8 & 0.6 & 0.0 & 0.0 & 0.0 & 100.0 \\
\hline Virginia & 1.3 & 0.8 & 8.7 & 5.3 & 0.0 & 0.0 & 0.0 & 64.6 \\
\hline Washington & 0.3 & 3.8 & 14.8 & 1.3 & 0.0 & 0.0 & 0.0 & 100.0 \\
\hline West Virginia & 0.7 & 5.1 & 13.3 & 0.2 & 0.0 & 0.0 & 0.0 & 0.0 \\
\hline Wisconsin & 1.0 & 0.3 & 8.3 & 0.0 & 0.0 & 0.0 & 0.0 & 0.0 \\
\hline Wyoming & 1.7 & 0.6 & 7.9 & 0.8 & 0.0 & 0.0 & 0.0 & 0.0 \\
\hline United States & 5.6 & 4.6 & 12.5 & 3.6 & 41.1 & 19.6 & 6.4 & 13.9 \\
\hline
\end{tabular}




\section{Appendix B. Historical Context of School Capacity Constraints and Calendar Conversions}

in California

California’s Proposition 13 passed in 1978 and initiated sweeping changes to the state and local property tax systems. This proposition limited property tax rates and prohibited local education agencies from issuing general obligation bonds to fund school construction projects. These limitations effectively shifted new school construction and renovations to the state who implemented the State Allocation Board (SAB). School districts needing to construct a new school or modify an existing facility were required to apply to the SAB through a competitive granting process. The administration of the grant was considered quite slow due to the reviewing, processing, and allocating phases of the grant, often without priority consideration. For example, to qualify for a new building, school district had to meet the minimum of 10 percent overcrowding, and could not use growth projections. The grant program culminated in the beginning of 1986 with the SAB having 339 applications for new construction and 901 applications for reconstruction requesting a combined $\$ 1.7$ billion (in 1986 dollars), a \$500 million shortfall from what legislation had approved (California Legislative Analyst’s Office (1986)).

In 1986, Proposition 46 was passed that permitted local municipalities to issue general obligation school construction bonds and required a two-thirds majority for passage, the same majority requirement pre-Proposition 13. The effect was 450 school districts sponsored 830 general obligation school construction bonds equaling \$485.8 million from 1986 to 1999 with a passage rate of $54 \%$, leading to $\$ 240.4$ million in school construction. While a first step, this did not alleviate overcrowding in the majority of school districts as passage rates varied significantly. In general, smaller districts did better than larger unified districts, $59 \%$ vs. $47 \%$, while elementary districts did better than high school districts, 62\% vs. 51\% (EdSource (2000)). Exacerbating overcrowding during this period was California's substantial growth in the school-aged population. Between 1987 and 1997, California public school enrollments increased by 160,000 to 190,000 students each year (U.S. Department of Education, 1997).

In an effort to reduce overcrowded schools, in 1998, the California legislature and Governor Pete Wilson establish a class size reduction program that mandated caps on the number of students per certified teacher in various grades. This research-based mandate supported by the California Teachers Association limited K-3 class sizes to 20 students, immediately creating overcrowding in otherwise uncrowded schools. After the first two years in effect, three out of five 
schools did not meet student-teacher ratios with $81 \%$ citing limited space as the central reason for noncompliance (Bohrnstedt and Stecher (1999)).

By 2000, overcrowding in schools became a serious concern, and four state laws targeted the epidemic (Propositions 39, 47, 55, and 1D). Proposition 39 created an exception to Proposition 46 by allowing schools an option for school construction bonds to gain passage with a 55\% voter threshold instead of two-thirds. This lead to 1,130 local public-school construction bond proposals valued at \$1.366 billion between 2000 and 2015 (see Figure B.1a). The passage rates averaged $78.9 \%$, leading to $\$ 1.1$ billion in actual school construction. Variation by the vote passage threshold caused starkly different school construction outcomes. As shown in Figure B.1b and B.1c, 940 bonds with a 55\% voter approval threshold had a passage rate of $82.4 \%$ while only 47.6\% of the 190 two-third voter approval threshold bonds passed (see Dayton (2015) for further analysis). Interestingly, bonds proposed on general election years have higher passage rates than off-cycle election years (see Figure B.1d). In 2002, Proposition 47 authorized the state to borrow \$13.1 billion (in 2002 dollars) to support matching grants for school and college construction projects. Similarly, in 2004 and 2006, Proposition 55 and 1D authorized the state to borrow \$12.3 billion (in 2004 dollars) and \$10.4 billion (in 2006 dollars), respectively, in second and third rounds of matching grants for school construction projects. Due to construction lags, schools were not operational until several years after bond passage. A snapshot of these three bills is provided in Table B.1. Overall, the matching grants funded 10,085 primary and secondary school facility projects at a cost of $\$ 31.9$ billion dollars and increased the number of new classrooms by 55,937 and modernized 132,276 classrooms. Modernization capital project refer to improves to existing infrastructure of some sort, e.g., roof replacement, plumbing upgrades, ADA upgrades, HVAC upgrades and may not necessarily change instructional technology and improve classrooms visibly.

Much of the increase in school construction was driven by existing overcrowding and forecasted increases in school-aged population of 168,000 students per year between 1999 and 2009 (U.S. Department of Education, 1999). This forecasted increase was anticipated to be larger than that of Alaska, Colorado, Hawaii, Idaho, Nevada, Oregon, Tennessee, Utah, Washington, and Wyoming (Ready et al. (2004)). As documented by the U.S. Census Bureau, the school-aged population in California only grew by 86,623 during the 10-year period (1999-2009). The substantial school construction increases and the lack of significant increase in school-aged 
population greatly reducing overcrowding within California public school during the early 2000s, reducing the reliance on multi-track year-round calendars. 
Figure B.1: California General Obligation Bond Election Statistics

Figure B.1a: LEA School Construction Bonds

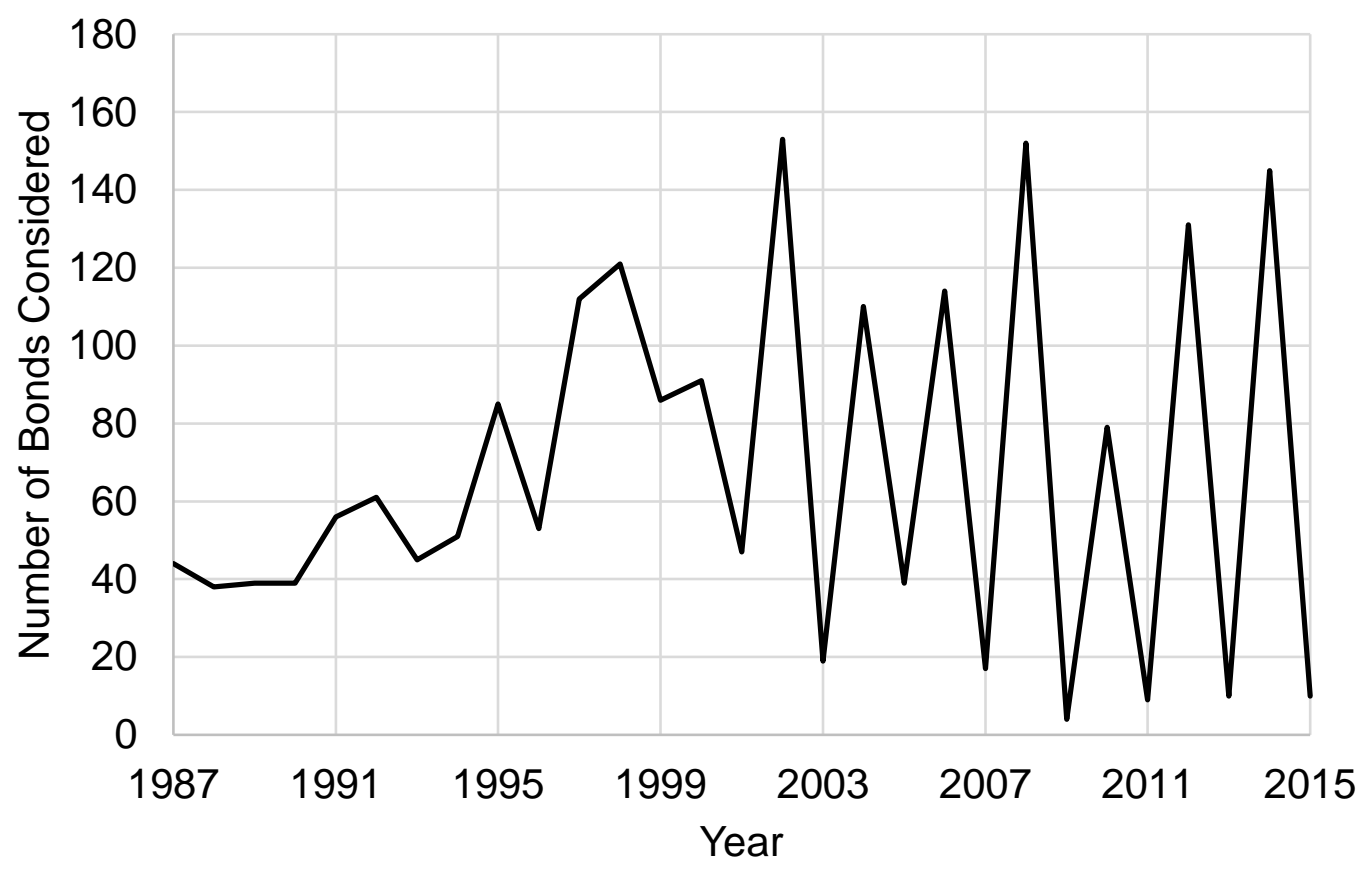

Figure B.1b: Bond Requiring 55\% Approval and Approval

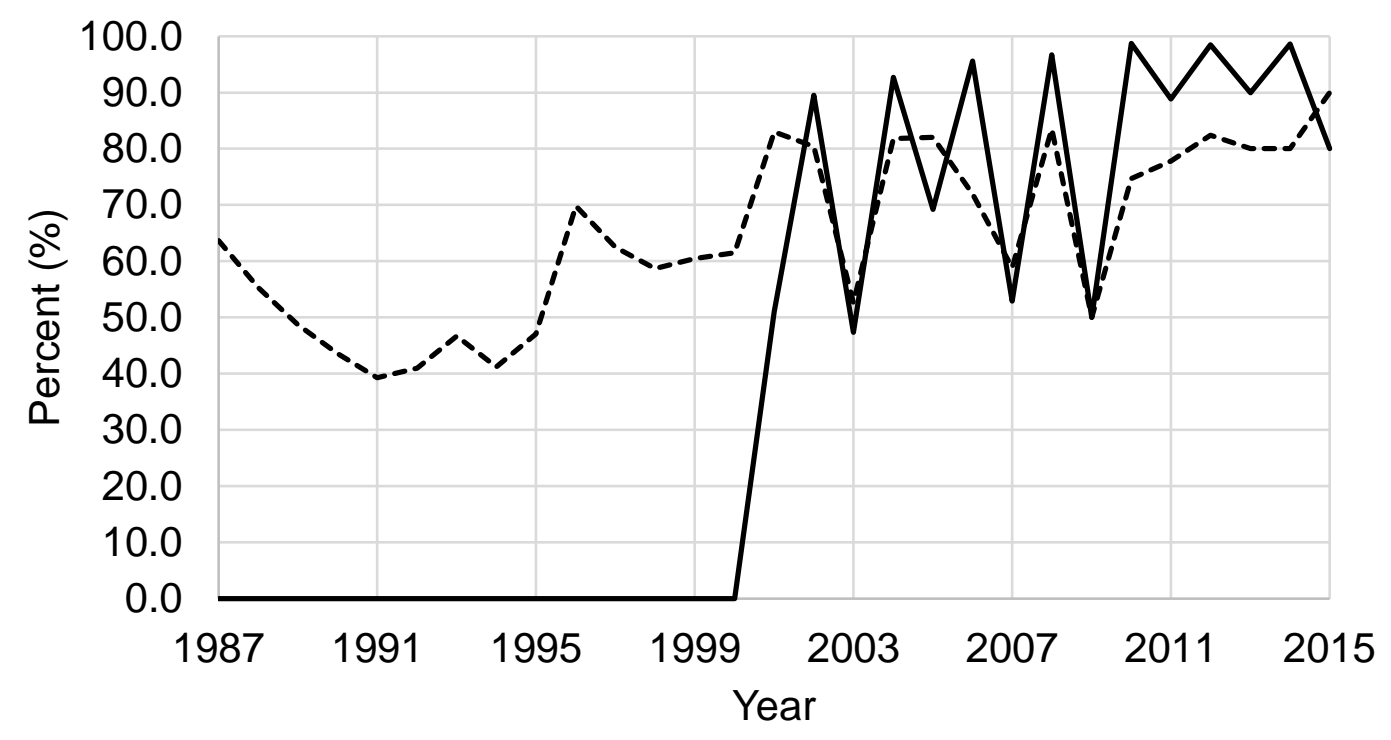

— Require 55\% Approval ------Approved 
Figure B.1 Con.: California General Obligation Bond Election Statistics

Figure B.1c: Annual Vote Share in Favor

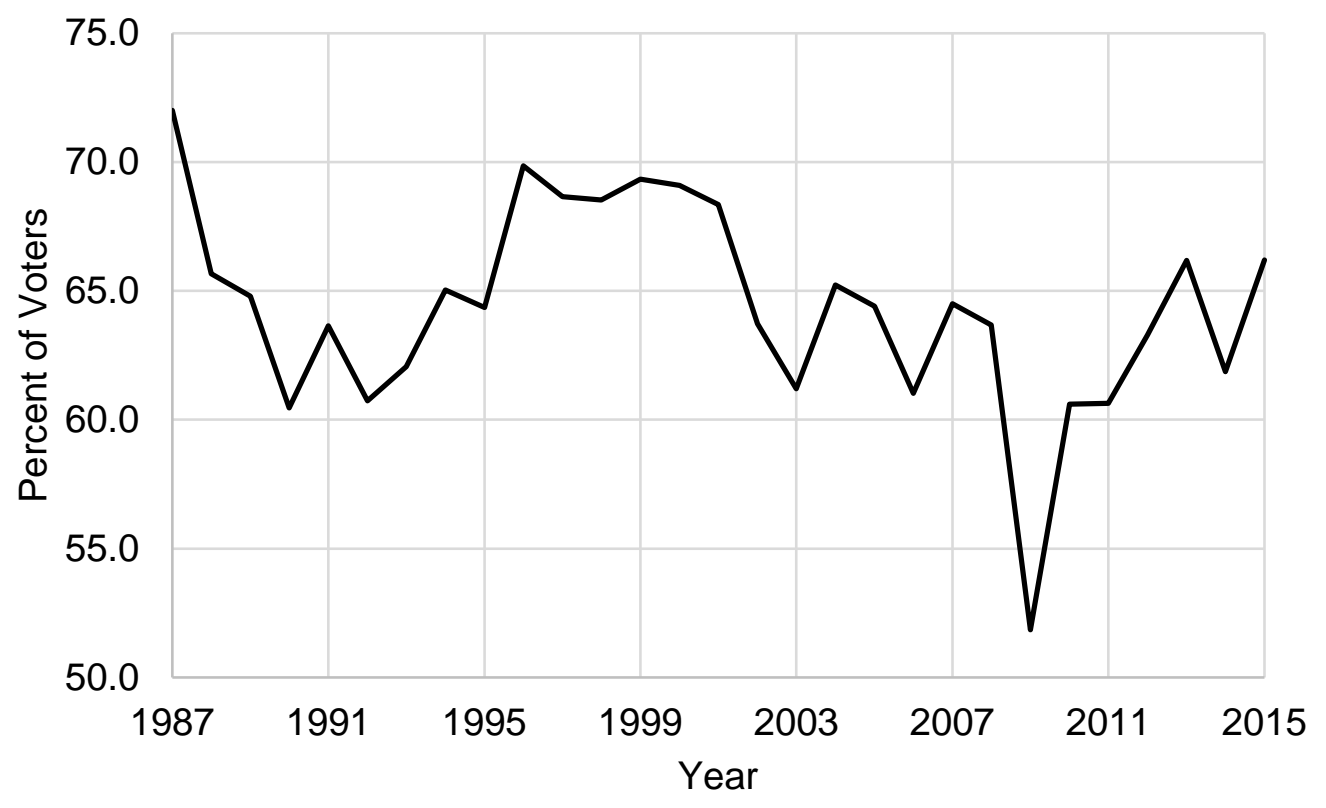

Figure B.1d: Value of Bonds and Bonds Approved

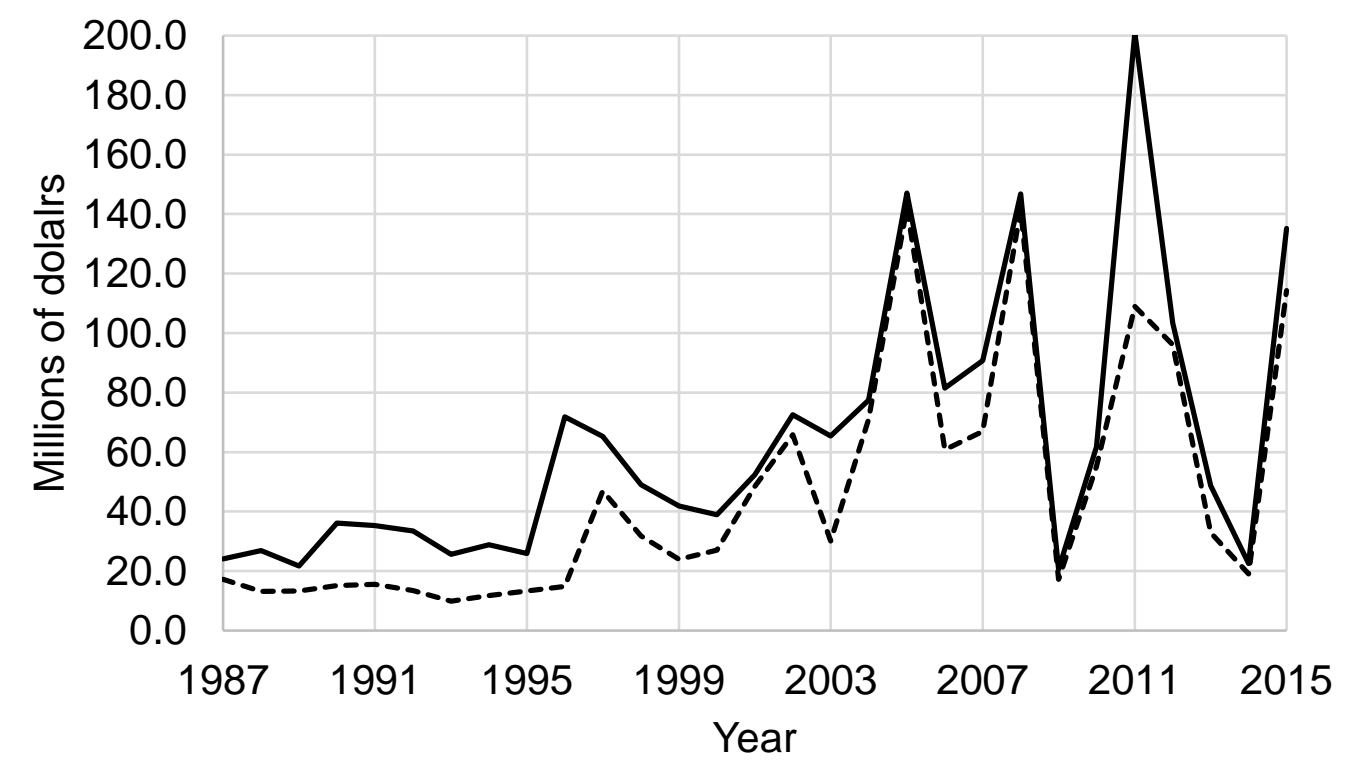

- Value of Bonds $\quad$------Value of Bonds Approved

Source: Ed-Source. Cellini et al. (2010) provide similar data for 1987 to 2006 and Dayton (2015) for 2007 to 2014. 
Table B.1: School Facility Program Summary Related to Primary and Secondary Education for Prop 47, Prop 55, Prop 1D

\begin{tabular}{|c|c|c|c|c|c|c|c|c|}
\hline & Projects $^{a}$ & $\begin{array}{c}\text { Number of } \\
\text { New } \\
\text { Classrooms }\end{array}$ & $\begin{array}{c}\text { Acres } \\
\text { Acquired }\end{array}$ & $\begin{array}{c}\text { State } \\
\text { Construction } \\
\text { Funds }^{\mathrm{b}}\end{array}$ & $\begin{array}{l}\text { State Site } \\
\text { Acquisition } \\
\text { Funds }\end{array}$ & $\begin{array}{l}\text { Financial } \\
\text { Hardship }\end{array}$ & $\begin{array}{c}\text { Total State } \\
\text { Apportionment }\end{array}$ & $\begin{array}{c}\text { Average } \\
\text { Construction } \\
\text { Funds Per } \\
\text { Projectc }^{c}\end{array}$ \\
\hline New Construction & 3,598 & 50,655 & 15,612 & $\$ 12,138,940,375$ & $\$ 2,282,222,740$ & $\$ 2,990,300,014$ & $\$ 17,411,463,129$ & $\$ 3,373,802$ \\
\hline Modernization & 6,221 & 132,276 & - & $\$ 10,527,153,128$ & - & $\$ 353,142,332$ & $\$ 10,880,295,461$ & $\$ 1,692,196$ \\
\hline Charter Schools ${ }^{d}$ & 62 & 932 & 155 & $\$ 600,836,661$ & $\$ 17,319,676$ & - & $\$ 692,321,165$ & $\$ 9,690,914$ \\
\hline Overcrowding Relief Grant & 100 & 1,358 & 102 & $\$ 584,521,814$ & $\$ 40,484,332$ & $\$ 44,213,229$ & $\$ 669,219,375$ & $\$ 5,845,218$ \\
\hline Critically Overcrowded Schools & 104 & 2,992 & 640 & $\$ 1,565,407,635$ & $\$ 744,826,333$ & - & $\$ 2,310,233,968$ & $\$ 15,051,996$ \\
\hline Totals & 10,085 & 188,213 & 16,508 & $\$ 25,416,859,613$ & $\$ 3,084,853,081$ & $\$ 3,387,655,576$ & $\$ 31,963,533,097$ & $\$ 2,520,264$ \\
\hline
\end{tabular}

